Cross-border Spillover Effects of Unconventional Monetary Policies on Swiss Asset Prices

Severin Bernhard and Till Ebner
SNB Working Papers
9/2016 


\section{DISCLAIMER}

The views expressed in this paper are those of the author(s) and do not necessarily represent those of the Swiss National Bank. Working Papers describe research in progress. Their aim is to elicit comments and to further debate.

\section{COPYRIGHT $\odot$}

The Swiss National Bank (SNB) respects all third-party rights, in particular rights relating to works protected by copyright (information or data, wordings and depictions, to the extent that these are of an individual character).

SNB publications containing a reference to a copyright (@) Swiss National Bank/SNB, Zurich/year, or similar) may, under copyright law, only be used (reproduced, used via the internet, etc.) for non-commercial purposes and provided that the source is mentioned. Their use for commercial purposes is only permitted with the prior express consent of the SNB.

General information and data published without reference to a copyright may be used without mentioning the source. To the extent that the information and data clearly derive from outside sources, the users of such information and data are obliged to respect any existing copyrights and to obtain the right of use from the relevant outside source themselves.

\section{LIMITATION OF LIABILITY}

The SNB accepts no responsibility for any information it provides. Under no circumstances will it accept any liability for losses or damage which may result from the use of such information. This limitation of liability applies, in particular, to the topicality, accuracy, validity and availability of the information.

ISSN 1660-7716 (printed version)

ISSN 1660-7724 (online version)

(C) 2016 by Swiss National Bank, Börsenstrasse 15,

P.O. Box, $\mathrm{CH}-8022$ Zurich 


\title{
Cross-border Spillover Effects of Unconventional Monetary Policies on Swiss Asset Prices*
}

\author{
Severin Bernhard ${ }^{\dagger}$ \\ Till Ebner $\ddagger$
}

August 10, 2016

\begin{abstract}
Unconventional monetary policies (UMPs) by the Federal Reserve, the European Central Bank, the Bank of England and the Bank of Japan exert important spillover effects on asset prices in Switzerland if market anticipation of UMP announcements is properly accounted for. Using a broad event set and a long-term bond futures-based measure as a proxy for market anticipation of the announcements, we show that the unexpected part of those UMPs boost Swiss government and corporate bond prices, induce the CHF to appreciate, and dampen Swiss equity prices. Four extensions provide additional insights: First, the estimated effects are strongest for announcements by the ECB. Second, the impact on government bonds is largest for bonds with residual maturities of 7-10 years. Third, the impact of foreign UMP shocks on exchange rates and Swiss bond yields is less pronounced after the introduction of the EURCHF-floor by the Swiss National Bank on September 6, 2011. Fourth, the sign of spillover effects differs for positive and negative UMP surprises, but their strength does not. Our results hint at an important role played by both international portfolio re-balancing channels and international signalling channels in the transmission of foreign monetary policy shocks to Swiss asset prices.
\end{abstract}

JEL classification: E52, E58, E65, F31, F42, G12

\footnotetext{
${ }^{*}$ We thank Fabrice Collard, seminar participants at the Swiss National Bank and an anonymous referee for helpful comments and suggestions. The views expressed here are those of the authors and do not necessarily reflect the position of the Swiss National Bank.

${ }^{\dagger}$ Swiss National Bank, Börsenstrasse 15, CH-8022 Zürich. E-Mail: severin.bernhard@snb.ch.

${ }^{\ddagger}$ Swiss National Bank, Laupenstrasse 18, CH-3003 Bern. E-Mail: till.ebner@snb.ch.
} 


\section{Introduction}

Empirical evidence strongly suggests that unconventional monetary policies (UMPs) implemented in response to the financial crisis exert significant spillover effects on global financial markets. In emerging market economies in particular, exchange rates, interest rates, equity prices and capital flows are shown to be affected by foreign UMPs. However, evidence regarding the spillover effects on advanced small open countries remains limited. To fill this gap, we empirically assess the impact of UMP announcements by the central banks of the four major currency areas - the US, Euro area, UK and Japan - on a broad range of Swiss asset prices (government and corporate bond yields, equities and exchange rates). Our analysis reveals that significant spillovers exist in the Swiss case, and four extensions indicate that these spillovers depend on the characteristics of the UMP announcement - such as the origin of the announcement and the sign of surprise -, the maturity of the bonds analysed and measures implemented by the Swiss National Bank (SNB).

Our study contributes to the literature in four respects: ${ }^{1}$ First, we focus on an advanced small open economy. Key contributions to date, such as Glick and Leduc (2012), Neely (2015) and Fratzscher et al. (2013), and policy debates are dominated by international monetary policy spillovers to emerging markets and among large advanced economies. Switzerland, one of the most globalized economies in the world, with a large financial sector and an internationally traded currency that is occasionally exposed to safe-haven demand, provides a particularly interesting case in this regard. Second, due to the exchange rate floor of 1.20 CHF per Euro that was enforced by the Swiss National Bank between 6 September 2011 and 15 January 2015, the Swiss case also allows us to examine the effectiveness of domestic monetary policy responses to external financial shocks. Third, we rely on a newly constructed set of nearly 100 UMP statements by the Fed, ECB, BoJ and BoE from 2008 to 2014, whereas a large part of the literature analyses only the first asset purchase program of the Fed. ${ }^{2}$ Fourth, this extended set of UMP events allows us to re-assess the results by Glick and Leduc (2012), who find that both the direction and strength of cross-border asset price effects differs between positive and negative UMP surprises.

The empirical strategy closely follows the linear time-series approach of Glick and Leduc (2012). It is based on two key elements: First, we evaluate the daily changes in Swiss asset prices on days with UMP announcements by foreign central banks. The timing of the announcements is pinpointed by our newly constructed event set. The second element is the extent to which financial markets anticipate the content of these UMP statements. We identify the surprise part of these statements using a market-based surprise measure that relies on the daily changes in the price of $10 \mathrm{y}$ government bond futures. We thus closely follow the approach proposed by Wright (2012). Controlling for market anticipation proves necessary to properly identify the impact of UMP announcements.

\footnotetext{
${ }^{1}$ To the best of our knowledge, although elements of the subsequent list have been covered elsewhere, no existing work provides such a comprehensive analysis of UMP spillover effects on advanced small open economies, or on Switzerland in particular.

${ }^{2}$ In this regard, the studies by Rogers et al. (2014) and Diez and Presno (2013) are closest to ours. However, these analyses rely on a different event selection scheme and focus mainly on the domestic effects and USD exchange rate effects of UMP announcements.
} 
We find that UMP announcements by the four major advanced central banks significantly affect Swiss government yields, equity prices and nominal CHF exchange rates. The size and direction of the effects depend heavily on the degree of policy anticipation and the asset class under consideration. We show that foreign UMP surprises tend to lower both Swiss bond yields and Swiss equity prices and induce appreciation of the CHF. An expansionary UMP shock equivalent to a 25-basis-point decline in local long-term bond yields induces an approximately 6-basis-point decrease in Swiss long-term government bond yields, a 4.5-basis-point decrease in long-term corporate bond yields, a 1-percentage-point decline in the Swiss equity index, an approximately 0.6-percentage-point appreciation of the CHF against the EUR and an approximately 0.9-percentage-point appreciation of the CHF against the USD. Unsurprisingly, the effects are strongest for UMP announcements by the ECB and, among government bonds, for those with residual maturities of 7-10 years. We further confirm the finding of Glick and Leduc (2012) that the sign of spillover effects differs between positive and negative UMP surprises, whereas we cannot lend support to their conclusion that the strength of spillover effects is larger for positively surprising announcements. The implementation of the EURCHF floor at 1.20 CHF per EUR tends to attenuate the spillover effects on bond yields and exchange rates but not those on Swiss equities. This result indicates that the domestic monetary policy stance exert some limited effect on the cross-border asset price impact of foreign monetary policy decisions. Although the chosen set-up does not allow for a formal analysis of the underlying channels through which these spillovers are transmitted, our results suggest an important role played by an international portfolio re-balancing channel in the transmission of foreign UMP shocks on Swiss bonds and by an international signalling channel in the reaction of Swiss equity prices.

The spillover effects are highly relevant from an economic perspective. On the announcement day, the unexpected part of foreign UMPs is responsible for large parts of the observed change in Swiss asset prices. Our estimates suggest that policy-induced spillovers are by and large responsible for the entire cumulative decline observed in Swiss longer-term government and corporate bond yields on UMP event days; they also account for approximately $60 \%$ of the cumulative decline in the Swiss Market Index and for approximately $35 \%$ and $40 \%$ of the appreciation of the CHF against the Euro and the USD, respectively.

The remainder of the paper is structured as follows. Section 2 reviews the theoretical and empirical literature on UMP spillover effects and, based on this review, develops our prior expectations regarding spillover effects on Swiss asset prices. Section 3 outlines the empirical set-up and data, section 4 describes the UMP event selection, and section 5 discusses the strategy used to identify monetary policy surprises. Empirical results are presented in Section 6, followed by a discussion of their robustness in section 7 . Section 8 concludes.

\section{Literature on unconventional monetary policy spillovers}

\section{$2.1 \quad$ UMP spillover channels}

In theory, unconventional monetary policies - both asset purchases (quantitative easing, QE, or credit easing, CE) and forward guidance (FG) statements by central banks - can exert cross-border spillover effects on financial assets through at least four channels: an international 
portfolio rebalancing channel, an international signalling channel, an exchange rate channel and a monetary policy reaction channel. ${ }^{3}$

First, for an international portfolio re-balancing channel to be at work, a high degree of substitutability between domestic and foreign bonds is a necessary precondition. In response to asset purchases by a central bank that lower yields domestically, optimizing investors will re-balance their portfolio internationally if there are foreign assets with a sufficiently similar risk-return profile. Assuming a constant supply of this foreign asset in the short-run, the portfolio rebalancing behaviour induces the domestic yield reduction to spillover to foreign yields. ${ }^{4}$ This process can be generalized as follows: Purchases of government bonds can increase the prices of other financial assets through their impact on available liquidity, the expected discount factor, the risk-taking behaviour of optimizing investors and the induced improvements in market functioning - this channel is thus sometimes referred to as the "asset price channel" or "liquidity channel". ${ }^{5}$

Second, UMP announcements exert international signalling effects through at least three subchannels: a policy reaction function channel, an economic outlook channel and a confidence channel. Regarding the first channel, a policy decision in a major economy may be read as a signal that other central banks will subsequently react in a similar way. Regarding the second and third channels, international signalling may be linked to the fact that market participants interpret an UMP announcement by a core central bank as containing news regarding the global economic outlook and/or the central banks assessment of global risk. Thus, an UMP announcement may influence market participants policy expectations, global risk assessment, and global income/cash-flow expectations, thereby inducing adjustments in risk pricing and in asset prices more generally. Ex ante, the net effect of the signalling channel on bond yields and asset prices is ambiguous, because the three sub-channels may mutually cancel or reinforce their individual impacts depending on whether markets on average interpret an announcement as positive or negative news about the global economic and financial situation. ${ }^{6}$

Third, monetary policy announcements - both conventional and unconventional - can have a significant bearing on exchange rates. Standard monetary models imply that a decrease in the policy rate - or, equivalently, an (expected) increase in the money supply - in one economy induces a depreciation of the nominal spot exchange rate of its currency. ${ }^{7}$ This theory is a consequence of Mundell's "Trilemma". In economies with open capital accounts, exchange rate fluctuations ensue in response to foreign monetary policy shocks if domestic monetary policy does not itself adjust in response. ${ }^{8}$ In the UMP era, monetary policies target longer-term interest rates more directly and thus the narrative is potentially more complex. Lower foreign long-term bond yields may reduce domestic long-term bond yields even if domestic monetary policy does not adjust. At the same time, even if domestic interest rates fall, exchange rates may still be

\footnotetext{
${ }^{3}$ Unlike with respect to conventional monetary policy channels, no settled consensus has been reached on the distinction and nomenclature of UMP transmission channels.

${ }^{4}$ He and McCauley (2013), IMF (2013a), Chinn (2013), and Berge and Cao (2014).

${ }^{5}$ For the "liquidity channel", see Krogstrup et al. (2012); for the discount factor view of asset prices, see Cochrane (2001); and for the role of monetary policy in risk-taking and improving market functioning, see Durré and Pill (2012).

${ }^{6}$ On signalling, see, for instance, Williams (2014) and Bauer and Rudebusch (2014).

${ }^{7}$ Krugman et al. (2011, chapter 14).

${ }^{8}$ E.g. Obstfeld et al. (2005).
} 
subject to appreciation pressure..$^{9}$

Fourth, and relatedly, the extent of the UMP announcement impact on asset prices across borders depends on the monetary policy reaction in recipient economies. In general terms, this channel implies that the recipient central bank chooses a policy that differs from the policy chosen in the absence of the foreign monetary policy innovation. This is, either domestic monetary conditions are kept at more expansionary levels for longer than they would be, for instance, under standard Taylor rules or balance sheet policies, such as foreign exchange market interventions, are implemented. Both an unexpected downward shift in the policy path and unexpected asset purchases tend to induce increases in domestic asset prices through standard domestic transmission channels. ${ }^{10}$

The net UMP spillover effect is the sum of the individual effects through each of these channels. The presence and strength of each channel depends on the asset class analysed, the specifics of the announced UMP programme, the global market conditions at the time of the announcement and, particularly for the signalling channel, whether markets coordinate on an optimistic or pessimistic interpretation of the policy announcement. In particular, although the 'fundamental' channels (i.e., the portfolio rebalancing and asset price channels) are at work throughout, the theoretical discussion suggests that an additional non-zero net effect of the international signalling channel may be present only at certain times. A key implication is that the reaction of different asset classes to foreign UMPs can differ substantially, possibly even with respect to direction. ${ }^{11}$

\subsection{Evidence on UMP spillovers}

Available empirical evidence robustly indicates that the value of the domestic currency falls and that global short- and long-term interest rates and corporate bond yields decline in response to expansionary UMP announcements in core economies, whereas the impact on global equity prices and capital flows are more ambiguous. ${ }^{12}$

The reported size and scope of asset price spillovers differ across recipient economies. The degree of global economic integration of the recipient economy in both financial and real terms is the first key determinant: the less friction in global financial markets, the higher the cross-border correlation in asset prices and hence the stronger the domestic asset price reaction to a foreign monetary policy shock. ${ }^{13}$ Second, both the size and direction of spillover effects depend on local

\footnotetext{
${ }^{9}$ This result can be linked to the fact that domestic long-term interest rates are more sensitive than short-term rates to global factors, whereas (short-term) exchange rate developments are driven, not the least, by expected short-term interest rate differentials, see Takáts and Vela (2014) and Kulish and Rees (2011).

${ }^{10}$ E.g. Taylor (2013), Chen et al. (2012b) or Caruana (2012).

${ }^{11}$ In general, risky assets such as equities react differently to monetary policy shocks compared to 'risk-free' assets such as government bonds, see the discussion in Doh and Connolly (2013).

${ }^{12}$ Diez and Presno (2013), Neely (2015), Glick and Leduc (2012), Glick and Leduc (2015), Berge and Cao (2014), Chen et al. (2012b), IMF (2013c), Fratzscher et al. (2013) and Ahmed and Zlate (2014).

${ }^{13}$ This holds in general, see Ehrmann and Fratzscher (2009). For the UMP era specifically, see Chen et al. (2012a, p. 227) and Caruana (2012). The former argues that "in a globalised financial market, leakage from domestic monetary easing is unavoidable, and the size of such leakage may differ across countries depending on the strength of the cross-border transmission channels". Caruana argues that the observed fall in global bond yields "simply reflects the thorough integration of global bond markets [...] The effects on asset prices are stronger for highly global markets, such as equities, and weaker for highly domestic ones, such as real estate".
} 
conditions ('pull factors') in the recipient country, such as the position of the local business cycle, the presence of imperfections in local markets, and the decisions and soundness of the institutional set-up of local macroeconomic policy. For instance, the analysis by Fratzscher et al. (2013) indicates that opting for a fixed exchange rate regime is no guarantee that individual countries will be insulated from financial spillovers induced by U.S. monetary policy shocks, which corroborates a more general result reported by Rey (2013). In addition, exchange rate developments not only represent an important channel for cross-border transmission of monetary policy shocks but also influence the size of spillover effects on other asset prices. That is, exchange rate changes may reinforce or dampen the cross-border asset price effect induced by the portfolio rebalancing/asset price and signalling channels discussed above. Moreover, the estimated size of these spillovers depends on the specific characteristics of the asset purchase programme implemented. ${ }^{14}$ In this regard, differences between programmes implemented by different central banks are of particular interest. However, comparative evidence remains scarce, because most existing UMP spillover studies focus on the cross-border impact of Fed policies. ${ }^{15}$

\subsection{Expected spillovers in the Swiss case}

The discussion of potential spillover channels is helpful to the formation of specific expectations regarding the cross-border impact of foreign UMP shocks on Swiss assets and facilitates the discussion of the empirical results, particularly with respect to the more granular analyses of spillover effects for different subsets of foreign UMP events. However, it is important to stress that the empirical set-up applied in this study does not allow for a formal identification of individual spillover channels, unlike, for instance, the analyses conducted by Fratzscher et al. (2014) or Bauer and Neely (2014).

Specifically, the literature review leads to the following expectations with respect to the direction of the impact of an expansionary foreign UMP shock on Swiss financial assets:

- The CHF is expected to appreciate in nominal terms. For the Swiss economy, the exchange rate channel is important, given exchange rate flexibility and the high degree of financial and real integration of the Swiss economy. ${ }^{16}$ At the same time, the signalling channels dampen the FX appreciation induced through the exchange rate channel by raising confidence levels (by reducing risk-aversion, thus dampening demand for safe haven currencies) and driving expectations of a domestic policy reaction.

- Swiss government bond yields are expected to fall. Given that Swiss government bonds are close substitutes for foreign government bonds, the international portfolio rebalancing channel is likely to be an important factor in explaining Swiss bond price reactions to foreign UMP announcements. The net effect of the international signalling channel is unclear ex ante. In any case, we expect it to be less important than the portfolio balancing effect. However, if a CHF appreciation effect is induced, the demand for Swiss bonds will

\footnotetext{
${ }^{14}$ Fratzscher et al. (2013), Chen et al. (2012b) and Christensen and Rudebusch (2012).

${ }^{15}$ Notable exceptions are Chen et al. (2012b), Diez and Presno (2013) and - in part - Rogers et al. (2014), as well as several policy papers by the IMF [IMF (2013c), IMF (2013b) and IMF (2013a)].

${ }^{16}$ For a classification of Switzerland as a highly financially and economically integrated small open economy, see, e.g. the KOF index of globalization in Dreher (2006).
} 
decrease as they become, ceteris paribus, more expensive for foreign investors, which in turn reduces the effect on their yields.

- Ex ante, the Swiss equity price reaction is ambiguous. A positive impact due to more available liquidity and lower discount rate expectations (global liquidity and asset-price channels) can be offset or even over-compensated through foreign exchange rate effects and international signalling effects. An appreciation of the CHF tends to reduce the competitiveness of internationally exposed Swiss firms and decrease their expected earnings, thus weighing on their share price. ${ }^{17}$ At the same time, appreciation of the CHF implies an increase in the price of Swiss equities for foreign investors, which dampens demand and hence prices. Signalling channels imply a negative effect on Swiss equities if the corresponding confidence boost implies that foreign risky assets are seen as more attractive than Swiss risky assets or if the downgrading of the global economic outlook dampens the cash flow expectations for Swiss corporations.

\section{Empirical framework and data}

The empirical assessment of UMP spillover effects on Swiss asset prices is conducted based on daily data. The basic specification estimated follows equation (1). We apply the time-series set-up as in Glick and Leduc (2012), using an explicit measure of the surprise component of policy announcements, following Wright $(2012) \cdot{ }^{18}$

$$
\Delta y_{t}=\alpha+\beta \Delta s_{t} d_{t, \text { events }}+\gamma^{\prime} \mathbf{z}_{t}+\varepsilon_{t}
$$

The dependent variable $\Delta y_{t}$ represents the change in the following Swiss asset prices: the main Swiss equity price index (Swiss Market Index, SMI) and bilateral CHF exchange rates (USD, Euro), measured as a one-day percentage change, and long-term government and corporate bond yields (GB 10y, CP 7-10y), measured as a one-day change in basis points.

The dummy variable $d_{t, \text { events }}$ takes the value of one on all days specified as foreign UMP announcement days and zero otherwise. The strategy adopted to designate specific days as UMP announcement days is explained in section 4 .

$\Delta s_{t}$ represents a quantitative measure of monetary policy surprise, that is, the extent to which a policy announcement differs from market expectations. The baseline measure used as a proxy for monetary policy surprise is the change in longer-term government bond futures (approximately $10 y)$. The underlying motivation for the use and the quality of this proxy is discussed in detail in section 5. The surprise measure for each central bank is set to its market-derived value on corresponding UMP announcement days. ${ }^{19}$

For several 'sub-sample' analyses, the explanatory variable $\Delta s_{t} d_{t, \text { events }}$ is interacted with a

\footnotetext{
${ }^{17}$ The large majority of the companies listed on the SMI are globally active.

${ }^{18}$ The approach is closely related to the event study approach commonly relied upon in the empirical UMP literature. An event study using a one-day event window and the same control variables as here, yields comparable results.

${ }^{19}$ In a follow-up analysis, we compare the estimated effects of this measure on Swiss asset prices on days with UMP announcements to the effects on days without such announcements.
} 
dummy for the implementation of the minimum exchange rate $\left(d_{t, m e r}\right.$, taking the value of one after 6 September 2011 and zero otherwise), dummies for each central bank $\left(d_{t, c b}\right.$, taking the value of one on days with announcements by the corresponding central bank), or a dummy for "positive" and "negative" surprises $\left(d_{t, \Delta s>0}\right.$ and $\left.d_{t, \Delta s<0}\right)$, taking the value of one for announcements that surprise markets positively and negatively, respectively), with positive surprises being announcements that are more expansionary than expected.

The vector $\mathbf{z}_{t}$ controls for global financial market conditions and asset-specific trends. The baseline set of controls comprises the one-day lagged values of the dependent variable, the oneday lagged change in the VIX, and the lagged change in the US 10y treasury yield. Overall, the results obtained are robust to the inclusion of a broad set of alternative controls, as discussed in section 7 .

We estimate equation (1) by OLS, accounting for potential heteroscedasticity based on White (1980). Serial correlation is not expected to be a crucial problem for changes in asset prices and is indeed dismissed by preliminary checks. ${ }^{20}$

Two main sources of bias are conceivable when assessing the impact of monetary policy on asset prices using such an event study-inspired set-up. ${ }^{21}$ First, reverse causality - i.e., the possibility that monetary policy or the measure of policy expectations reacts to changes in asset prices must be taken into consideration. In general, monetary policy decisions are taken as a function of economic and financial conditions. Hence, market developments may influence policy decisions. ${ }^{22}$ Second, other important news, such as GDP releases or labour market data released during the measurement window (in this case, on the same day as a monetary policy announcement) may simultaneously affect asset prices and the market-based measure of monetary policy surprise. In other words, the possibility of an omitted variable bias must be taken into account.

Different approaches are proposed to address these potential sources of bias. One possibility is to restrict the measurement of changes in the surprise measure and asset prices to a highfrequency window spanning only minutes - or at most, hours - around policy announcements. ${ }^{23}$ Although the initial impact is measured more sharply, this approach has one key drawback: Markets may initially misinterpret policy announcements, leading either to an over-reaction or an underestimation of the "true" effect on asset prices. Thus, the length of the measurement window should allow markets sufficient time to fully price in the policy news. This issue may be particularly important in the case of UMP announcements, which are more difficult to interpret than conventional adjustments in the policy rate.

We apply a different strategy and retain the daily measurement window, relying on control variables to take account of previous trends in asset prices and market developments, which could be triggers of subsequent policy interventions and asset price changes. Integrating the baseline controls contributes to effective containment of potential endogeneity issues. Moreover,

\footnotetext{
${ }^{20}$ The assumption of normally distributed coefficients seems robust, although asset price changes per se follow a t-distribution rather than the normal. While tests for normally distributed asset prices changes do indeed reject the null of normal distribution, corresponding tests for non-parametric bootstrapped coefficients do not - we are thus confident in assuming this distribution for the coefficients. At the same time, estimation based on a GARCH specification of the variance structure yields qualitatively similar results.

${ }^{21}$ For an overview of the strengths and limits of the event-study approach, see Gürkaynak and Wright (2013).

${ }^{22}$ E.g. Rigobon and Sack (2003).

${ }^{23}$ This is the strategy adopted, for instance, in Rogers et al. (2014).
} 
testing for Granger causality in our data set suggests that the surprise measure relied upon is not driven by past asset price developments. In any case, from a central banking practice perspective, policy decisions are unlikely to be made based on short-run developments in asset prices, which by itself reduces the relevance of the endogeneity bias. ${ }^{24}$

Obviously, using daily data can increase the omitted variable bias problem because it does not account for the potential impact of other (non-monetary policy) news on asset prices during the measurement window. Essentially, increasing the length of the measurement window involves a trade-off between adding noise and allowing markets sufficient time to process the policy news. Our reading of the existing literature on the asset price effects of monetary policy suggests that a one-day window is a reasonable compromise. In most cases, for both conventional and unconventional monetary policies, results based on intra-day data are qualitatively similar to those based on daily data. ${ }^{25}$ More generally, the literature asserts that both endogeneity and the omitted variable bias are rather minor issues, at least when estimating the asset price effects of conventional monetary policy. ${ }^{26}$

\section{Data}

The financial market data are provided by Bloomberg. Appendix A provides a detailed description of the variables and sources. The sample data set spans from January 2008 to December 2014, containing 1827 potential non-weekend observation days. Depending on trading holidays and data availability, the effective number of observations entering the analysis varies among the individual assets, ranging from 1688 to 1763 . Ninety of those observation days are designated as UMP event days using the identification strategy outlined below in section 4 below. We compute one-day changes as the difference in basis points (for bond yields) and the percentage change (for the equity index and exchange rates). Due to Swiss trading hours, announcements by the Fed released after 10.45 a.m. local time (CET) are assumed to affect Swiss equity and bond prices one day after the announcement is made, whereas exchange rates are affected on the announcement day. ${ }^{27}$ Given the standard release time of Fed announcements (2.15 p.m. $\mathrm{CET}$ ), the day for measuring bond and equity prices shifts for a majority of Fed statements in our event set. All BoJ announcements are released before trading opens in Switzerland. Therefore, they are assumed to affect Swiss asset markets on their release day. For ECB and BoE announcements, time zone differences do not matter. Two ECB statements are released on a Sunday and are thus assumed to affect Swiss asset markets on the subsequent Monday.

\footnotetext{
${ }^{24}$ Endogeneity should be even less of an issue in the small open economy case considered in this study. Swiss asset price developments are very unlikely to affect foreign monetary policy decisions or foreign asset markets more generally.

${ }^{25}$ Gürkaynak et al. (2005) for CMPs; Glick and Leduc (2015), Rogers et al. (2014) and Wright (2012) for UMPs.

${ }^{26}$ Rigobon and Sack (2004), Rosa (2011) and Gürkaynak et al. (2005).

${ }^{27}$ Swiss equity and bond market closure times, which are the cut-off points for daily values, vary between 5 p.m. and 6 p.m. Swiss time, in contrast to the cut-off point for exchange rates, which is 10 or 11 p.m. Swiss time. For the purpose of our analysis, we assume that US announcements made after 4.45 p.m. Swiss time affect Swiss equity and bond prices on the day following the announcement. One UMP event (a TALF extension on 10 February, 2009, which was released at 5 p.m. Swiss time) would be affected by a shift in the cut-off threshold from 5 p.m. to 6 p.m. An alternative approach to circumvent time zone-related issues is to rely on a two-day measurement window, see section 7.3.
} 


\section{Event set}

Estimating the impact of unconventional monetary policy announcements requires an appropriate, robust identification of unconventional monetary policy shocks. Identification entails two steps. First, a definition of the analysed policy events. That is, when information about a specific policy was released must be determined. ${ }^{28}$ Second, once these events are designated, a valid and robust measure of policy surprise - the policy shock - is needed. This step asks exactly what markets learn from a policy announcement. This section explains the strategy underlying the designation of UMP events (when), and section 5 explains the strategy used to identify the extent of policy surprise (what).

\section{Crisis narrative}

The specific UMP events are selected based on the narrative approach of policy shock identification, similar to the procedure applied by Romer and Romer $(1989,2004)$. To viably conduct such an approach, we must first outline the narrative of the crisis that evoked the unconventional policy response. ${ }^{29}$

The first signs of crisis appeared in August 2007 as tensions in global interbank funding markets. Central banks around the globe addressed these tensions by providing ample liquidity through a wide range of emergency facilities, including the Term Auction Facility used by the Fed and the Special Liquidity Scheme implemented by the BoE. At the same time, central banks established foreign currency swap lines to contain liquidity strains in global financial markets. These programmes aimed to restore the functioning of the short-term interbank funding markets. By implementing these programmes, central banks fulfilled their mandated role as the lenders of last resort, committed first and foremost to securing financial stability.

With the failure of Lehman Brothers in September 2008, the crisis increasingly impaired credit markets and spread to the real economy. In reaction, monetary policy measures designed to repair credit market functioning and to ease monetary conditions more generally took centre stage, first by swiftly lowering policy rates to levels near zero and subsequently by expanding the size and altering the composition of the central banks balance sheets and providing more explicit guidance on the future path of the policy rate (Forward Guidance). Thus, these policies went significantly beyond traditional interest rate policy. Given their design, size and scope, these policies are usually referred to as unconventional monetary policies (UMPs). Although the programmes implemented by individual central banks are similar in their general objectives i.e., repair disrupted credit markets, ensure smooth monetary policy transmission, and support economic activity - their specific designs, scopes and timing vary substantially across central banks. ${ }^{30}$ As an example of such differences, it is worth noting that during the first phase of crisis escalation in late 2008, the Fed and BOE announced outright large-scale asset purchases, whereas the ECB and BOJ focused primarily on programmes that support loan supply through

\footnotetext{
${ }^{28}$ Faust et al. (2007).

${ }^{29}$ For detailed narratives of the crisis and policy responses, see Fawley and Neely (2013), Lenza et al. (2010), Cour-Thimann and Winkler (2012) and Rogers et al. (2014).

${ }^{30}$ Such differences mainly reflect variations in economic and financial structure (for instance, whether corporate financing is predominantly bank-based or market-based) and the conditions of the specific domestic market and economy.
} 
banks. $^{31}$

Tables 11 and 12 provide short descriptions of the key unconventional monetary policy programmes implemented by the four central banks between 2008 and 2014 .

\section{Event set}

Building on this crisis narrative, the set of UMP announcements - the event set - used in the empirical analysis is constructed based on a thorough analysis of statements issued by the four central banks through press releases, media conferences and governor speeches. The following criteria are applied to designate an announcement as an UMP event.

First, because our study focuses on measures aimed at securing monetary and macroeconomic stability, only those liquidity measures implemented predominantly for monetary policy reasons are included in our definition of UMP programmes; those focused mainly on financial stability are excluded. Hence, the first announcement entering as an UMP event dates in 2008. Obviously, it is not always easy to make an unambiguous distinction between liquidity provision programmes implemented as financial stability policies and those implemented for monetary policy reasons. To make the distinction, we rely on the crisis response narrative outlined above and an analysis of the key objectives of individual policy programmes as stated in their official descriptions.

Second, among the monetary policy announcements entering this group, announcements that do not include any changes in wording - i.e., contain no intended news - regarding an UMP programme (for instance, a mere confirmation that a previously announced programme will continue) are not included in our baseline event set. In this regard, our approach differs from those of Diez and Presno (2013) and Rogers et al. (2014), who base their analyses of exchange rate effects on all official (scheduled) governing board meeting statements over the course of the crisis. The key advantage of the more restrictive approach applied here is that it mitigates the problem caused by a large number of no news events, i.e., the creation of noise, which weakens identification. One might argue that disregarding these events excludes the conceivable situation in which markets are expecting a central bank to move, but no move is announced. Although this argument is clearly important in theory, practical experience suggests that this problem is contained during the crisis because policy makers worked hard to ensure that markets knew in advance that policy would be changed on a specific day; the issue of surprise mainly concerns the scale of an announced policy change, not the change per se. In any case, we check the robustness of our event set selection by estimating the spillover effects based on an event set containing all monetary policy-related statements of the policy-setting bodies of the four central banks during our sample period. ${ }^{32}$

The baseline selection approach yields 97 UMP policy announcements - 34 by the Fed, 20 by the ECB, 16 by the BoE, and 27 by the BoJ. In seven instances, two different central banks

\footnotetext{
${ }^{31}$ With respect to the scope of asset purchase programmes, the following distinctions can be made: The BoE, BoJ, and ECB purchased assets with private credit risk exposure to remove that risk from the private sector balance sheets. The Fed, BoJ, and BoE resorted to purchases of long-term assets to stimulate the economy through traditional interest rate channels by reducing the average duration held in the private sector. At the same time, all four major central banks conducted asset purchases through credit facilities to improve the functioning of specific markets.

${ }^{32}$ The list of additional statements contains all press releases or press conferences following regular, scheduled monetary policy council meetings that do not contain news regarding UMP programmes.
} 
release a statement on the same day; hence, the event set entering the estimation comprises 90 identified event days. The enlarged event set used for robustness contains 379 announcements, of which 73 were announced by the Fed, 98 by the ECB, 92 by the BoE, and 104 by the BoJ.

\section{Monetary policy surprise}

The comparatively large number of announcements in our event set mitigates a crucial limitation of most studies on the impact of UMP announcements, namely, restrictions on inference and interpretation due to the small number of observations. However, given our expanded set of announcements, it is no longer plausible to argue that all events are fully surprising to market participants. Rather, it is appropriate to assume that market anticipation of unconventional policy announcements improves over time. ${ }^{33}$ We therefore need an explicit measure of the anticipation of the content of a monetary policy announcement to correctly gauge the impact of policy statements on asset prices.

\section{Baseline surprise measure: Change in long-term bond futures}

We use the daily change in 10-year government bond futures as a proxy for the extent of market surprise linked to unconventional monetary policy announcements according to equation (2). The change in futures prices are standardized by their standard deviation to ensure comparability among the measures for different economies. A positive change of the surprise measure - i.e., an increase in the futures price of the longer-term bond - is interpreted as a more expansionary policy than expected by market participants. More specifically, on average, a one-standarddeviation increase in the surprise measure implies a reduction in the corresponding domestic 10-year government bond yield of approximately $6 \mathrm{bp}$ for US, German and UK yields and approximately 2 bp for Japanese yields.

$$
\Delta s_{t}=\frac{f_{t}^{10 y}-f_{t-1}^{10 y}}{\sigma_{\Delta} f_{t}}
$$

By relying on a market-based measure of monetary policy surprise, we closely follow the state of the art in the literature for assessing the asset price impact of conventional monetary policy announcements. ${ }^{34}$ Although different measures have been proposed, Gürkaynak et al. (2007) indicate that the changes in federal funds rate futures best capture unexpected changes in the policy rate target. To fully capture monetary policy surprise, it is also necessary to include the change in longer-term financial instruments, such as term federal funds, term eurodollars, or eurodollar futures. Changes in these instruments reflect unexpected changes in the future path of the policy rate. ${ }^{35}$ However, for our study, which focuses on a period defined by short-term

\footnotetext{
${ }^{33}$ E.g. McLaren et al. (2014). To circumvent this issue, many studies on UMP effects focus exclusively on the early rounds of UMP announcements, such as the UK QE1 or Fed LSAP1 programmes, arguing that these announcements can confidently be assumed to be fully surprising, see, e.g., Gagnon et al. (2011) or Joyce et al. (2011).

${ }^{34}$ Krueger and Kuttner (1995) and Kuttner (2001).

${ }^{35}$ For a detailed discussion of measures for capturing conventional policy surprises, see Gürkaynak et al. (2005), Poole et al. (2002), Rigobon and Sack (2004) and Piazzesi and Swanson (2008).
} 
interest rates at or close to its lower bound, federal funds rate futures do not provide a reliable proxy for the expected course of monetary policy. This is because short-term futures rates are asymmetrically distributed in the presence of a lower bound. Moreover, when monetary policy is more explicitly geared towards the direct influence of long-term interest rates through changing risk and term premia, the expected short-term policy rate plays a less crucial role as an indicator of the policy stance. Essentially, the size of the balance sheet of the central bank takes over the role as key policy indicator. Unfortunately, there are no readily available (market-based) measures of the expected future size of a central banks balance sheet. ${ }^{36}$ Alternatively, in the UMP environment, one can assume with confidence that longer-term interest rates take on the role of policy target indicators and thus search for proxies that perform well in terms of capturing a surprising change in this (implicit) policy target. ${ }^{37}$ Against this background, Wright (2012) proposes relying on high-frequency changes in longer-term futures rates as a market-based proxy for the surprise component in unconventional monetary policy announcements. ${ }^{38}$

Our policy surprise measure is closely related to the UMP surprise measure proposed by Wright, which is also used in Diez and Presno (2013) and Glick and Leduc (2012), but substantially reduces its complexity. ${ }^{39}$ First, we disregard the extraction of principal components from a broad range of futures contracts. Second, we rely on the change in these medium-term futures prices as a simplified approximation of their yields. Third, whereas Wright calculates intra-day changes in the futures yield, we rely on day-to-day changes. These simplifications allow us to use the same policy surprise proxy for all central banks and to circumvent issues regarding the limited scope of bond futures data for non-US economies and the differences among futures contract specifications across borders.

\section{Quality of the baseline surprise measure}

Because we rely on a market-based measure, it is not inconceivable that other market developments in addition to the policy announcement induce changes in this measure, particularly because we consider its daily changes. As previously discussed in section 3, this possibility po-

\footnotetext{
${ }^{36}$ Some studies use the observed change in balance sheet size or actual asset purchases to quantify the change in the stance of unconventional monetary policy. However, these approaches are purely backward-looking and thus are not useful as measures of policy expectations, see Fratzscher et al. (2013) and Meaning and Zhu (2011).

${ }^{37}$ For applications in this spirit, see Gertler and Karadi (2015) and Kiley (2014).

${ }^{38}$ Although there is broad consensus on the best (market-based) measure to capture the surprise content of conventional monetary policy announcements, a consensus has not yet emerged for measuring UMP surprises. The literature suggests both quantitative and qualitative alternative proxies. Quantitatively, one alternative is to take account of pre-event developments in financial markets, see, e.g., Fratzscher et al. (2013). A second alternative is to use changes in the lagged dependent variable under scrutiny. In this spirit, Aitt-Sahalia et al. (2012) use the difference between the asset price change on event day and its average daily change on the twenty days preceding the policy event. A third alternative that is similar but not identical to our baseline measure is the use of longer-term government bond forward rates, see, e.g., Chadha et al. (2013). Fourth, changes in shadow policy rate estimates may prove useful for capturing the change in the monetary policy stance in an UMP/ZLB environment, see Wu and Xia (2014) or Lombardi and Zhu (2014). Qualitative measures of UMP expectations include survey-based data, such as the Reuters survey of London City economists (used, e.g., in Joyce et al. (2011) for the analysis of BoE UMPs), the Primary Dealer Survey (PDS) conducted by the New York Fed one week before each FOMC announcement (used, e.g., in Cahill et al. (2013)) and an ex-post analysis of newspaper articles on the market assessment of policy announcements (used, e.g., in Rosa (2012) and Lambert and Ueda (2014).)

${ }^{39}$ Specifically, Wright (2012) uses two-, five-, ten- and thirty-year government bond futures contracts to compute changes in the yields of these futures in a short window spanning 15 minutes before to 1 hour and 45 minutes after a policy announcement. The futures yield change is approximated by dividing returns by the duration of the cheapest-to-deliver underlying bond. The first principal component of these changes in futures yields is then used as a proxy for the monetary policy shock.
} 
tentially reduces the quality of this measure as clean identifier of monetary policy surprise. To verify that this issue is minor, we show that bond futures are a good proxy for news in general and thus are a good proxy for monetary policy news during the UMP period.

By construction, the announcements days selected in our event set contain news or a surprise regarding UMP. Hence, any good surprise proxy must - on average - exhibit stronger dispersion on these days than on days not selected as event days. As shown in Table 1, descriptive statistics reveal that changes in long-term futures indeed fluctuate more strongly on announcement days. Unconditional means and standard deviations of the daily change in long-term bond futures prices are considerably higher on event days than on non-event days. With the exception of BoJ announcements, dispersion is roughly 1.5 to 2 times higher on event days suggesting that the change in long-term government bond futures is a fairly well-suited proxy for market surprise on these days.

\section{$<$ Table 1 about here $>$}

Table 2 shows the correlation between changes in bond futures prices - the baseline proxy for market surprise - and changes in the corresponding local long-term interest rate - the implicit policy target in the UMP era. Overall, reported correlations are close to 1 in absolute terms. Moreover, the correlations are higher on event days than on non-event days. Considering these two results together suggests that the baseline surprise measure is not only a good proxy for market surprise in general but also particularly well-suited for capturing news regarding unconventional monetary policies.

Notably, the summary statistics imply that ECB announcements are, on average, negatively surprising, whereas the surprise in announcements by the other central banks is, on average, positive. Intuitively, this feature of ECB announcements can be linked to the fundamental difficulties of implementing policies equally in all economies within the entire monetary union. This issue is further analysed in the robustness section.

$$
<\text { Table 2 about here }>
$$

\section{Empirical results}

The first step in the empirical analysis is to gauge the average response of Swiss asset prices to foreign UMP announcements without controlling for the extent of market surprise entrenched in such announcements.

Summary statistics indicate that one-day changes in all Swiss asset prices considered are substantially larger in absolute numbers on days with UMP announcements than on days without UMP announcements, see Panels $1 \mathrm{a}$ and $1 \mathrm{~b}$ of Table 3 . The corresponding conclusion that the days designated as events are 'special' - that is, that they are surprising or reflect news of some sort - is also supported by higher standard deviations of asset price changes on event days.

Regressing asset price changes on an UMP announcement day dummy without controlling for the extent of the surprise reveals that foreign UMP announcements have no significant impact on Swiss bond and equity prices, whereas the Swiss franc bilateral exchange rate appreciates, on 
average, on days with UMP announcements by foreign central banks, see Panel 2 of Table $3 .{ }^{40}$ However, as discussed in section 5, the results tend to be biased if we do not control for market expectations regarding the policy announcements. In sufficiently efficient financial markets, only unexpected changes ('news') of monetary policy should have a systematic impact on asset prices. It is therefore likely that the set-up used for the first regression mis-measures the true extent of anticipation and thus the true effect of foreign policy announcements on Swiss asset prices.

\subsection{The key role of market expectations}

Results change considerably when we include our benchmark proxy for market surprise - the change in long-term government bond futures - as an explanatory variable instead of relying exclusively on a dummy. Formally, we estimate equation (1).

Panel 3 of Table 3 provides the point estimates using the entire event set as specified in section 4. Swiss long-term government and corporate bond yields and Swiss equity prices decrease in response to a positively surprising UMP announcement, and the CHF appreciates against the USD and the Euro. All estimates reported are significantly different from zero on a fairly high level. ${ }^{41}$

\section{$<$ Table 3 about here $>$}

The bond yield results are in line with intuition and theory. Swiss long-term bonds tend to be an adequate substitute for foreign long-term bonds, i.e., the international portfolio channel appears to be a crucial pillar in explanations of how foreign UMPs spillover to Swiss government bonds. ${ }^{42}$ This decrease in long-term government bond yields also transmits to long-term corporate bond yields through standard transmission channels.

The negative response of the SMI to announcements suggests that in the case of Swiss equities, the foreign exchange channel and international signalling channel outweigh the positive impact on Swiss equities of foreign expansionary surprises transmitted through the international asset price channel and global liquidity channel. ${ }^{43}$ Once again, the estimated effect on bilateral exchange rates is again in line with intuition, with an expansionary foreign UMP inducing the foreign currencies to lose in value.

The control variables influence Swiss asset prices as expected. An increase in overall market uncertainty - indicated by an increase in the VIX - lowers the prices of risky Swiss assets. The US long-term bond yield covaries positively with Swiss government and corporate bond yields, providing further evidence of the importance of cross-border asset market interlinkages. The lagged dependent variables do not affect changes in same-day asset prices, which is in line with

\footnotetext{
${ }^{40}$ Similar results are obtained if we split the event set by central bank, between expansionary and restrictive policy announcements (based on our judgment of the intention of the corresponding central bank), or by the day of introduction of the minimum exchange rate.

${ }^{41}$ Statistically, the overall explanatory power of our model for the variation in asset prices as measured by $R^{2}$ is small. This result is not surprising, given the specification applied (a time-series approach with dummies) and the low ratio of event days to non-event days in our sample.

${ }^{42}$ Section 6.4 discusses the impact on the entire Swiss government bond yield curve in more detail.

${ }^{43} \mathrm{~A}$ glance at the immediate spillover effects of UMP surprises on equity indices in other small open countries hints at similar results. A more thorough analysis of such spillover effects on a broader set of economies is left for future research.
} 
intuition informed by the efficient market hypothesis. Nonetheless, these variables are included in all analyses for identification reasons, as in section 3.

\section{By central bank}

Thus far, announcements by the various central banks have been analysed together. Thus, bilateral asset price effects may be disguised. A more granular analysis separating the announcements by corresponding central banks - i.e., multiplying $\Delta s_{t} d_{t, \text { events }}$ in equation (1) by a dummy $d_{t, c b}$ for each (foreign) central bank - provides a better reading of bilateral effects. ${ }^{44}$

$$
<\text { Table } 4 \text { about here }>
$$

The results reported in Table 4 broadly confirm the theoretical discussion in section 2 that suggests the depth of financial linkages to be an important explanation of the strength of crossborder spillover effects. ${ }^{45}$ ECB announcements exert the strongest and broadest impact on Swiss asset prices, followed by US and UK announcements, whereas BoJ events are shown to have only limited or no impact on the assets considered. Moreover, the estimates hint at significant effects of UMPs announced by corresponding central banks, particularly for the USD, on bilateral CHF exchange rates. As an aside, Table 4 reveals important indirect FX effects, with US events exerting an effect on EURCHF and UK events impacting the USDCHF. ${ }^{46}$

Less intuitively, Fed and BoE statements do not have significant effects on Swiss equities, whereas BoJ events do. The U.S. and UK results indicate either that the effects of different channels (e.g., signalling and liquidity effects) cancel each other out in the Swiss case or that that the announcement effects per se are in fact negligible. For the BoE specifically, this result can be linked to the comparatively low relevance of the UK economy for Swiss enterprises. The BoJ result is significant on the 5\%-level only, and is largely driven by the QQME announcement of 4 April 2013. BoJ events have no significant effect on the SMI when taking this outlier into account, which is more in line with intuition. ${ }^{47}$

\subsection{Impact of SNB's minimum exchange rate}

The introduction of an exchange rate floor of 1.20 CHF per EUR by the Swiss National Bank on 6 September 2011 - called the minimum exchange rate (MER) - provides a perfect setting to test the impact of domestic monetary policy decisions on the measured size and scope of asset price spillovers of foreign monetary policy shocks. ${ }^{48}$ To evaluate whether the spillovers are

\footnotetext{
${ }^{44}$ The resulting surprise series takes the value of the local surprise on the day of an UMP announcement by the corresponding central bank and is zero otherwise. The number of events per central bank ranges from 16 to 34 .

${ }^{45}$ When comparing the reported numbers, we must be aware that the standardization of the surprise measure has an important impact on the size of the coefficients of events by different central banks.

${ }^{46}$ Note that arbitrage conditions for currency triangles, e.g., the Euro, USD and CHF, and the different sizes of bilateral exchange rate markets may affect and thus hamper a clean interpretation of these results. Without further investigations, e.g., considering EURUSD, the indirect FX effects (and even the direct effects) should be interpreted with caution.

${ }^{47}$ The QQME announcement marked an important change in the BoJ monetary policy regime by substantially increasing its efforts to fight deflation. The QQME is a comprehensive programme, encompassing a change in the main operating target from an overnight call rate to monetary base and a substantial increase in the size of asset purchases.

${ }^{48}$ In addition, from a statistical perspective, the introduction of the MER enhances identification of the bilateral exchange rate effects. A successful minimum rate will necessarily lead to more limited FX effects - for the EURCHF
} 
significantly affected by this exceptional change in policy in the recipient country, we interact the $\Delta s_{t} d_{t, \text { events }}$ term in equation (1) with a dummy $d_{t, m e r}$. This dummy takes the value of 1 for the time period during which the minimum exchange rate was in place.

Table 5 provides the corresponding summary statistics and estimation results. The summary statistics in Panels 1a and 1b suggests that the implementation of the MER in September 2011 has an important impact on the average asset price reaction to foreign UMP announcements: after the MER introduction, the average changes are clearly smaller in absolute value for all assets. Moreover, with the exception of 10y government bond yields, the unconditional asset price changes on announcement days are positive on average, whereas they are negative in the before-MER sample. Additionally, the dispersion of asset price reactions on days of foreign UMP announcements is more muted after the implementation of the MER.

\section{$<$ Table 5 about here $>$}

Thus, at first glance, the summary statistics support the hypothesis that the spillover effects of foreign policies on Swiss asset prices were contained during the time of MER enforcement.

The econometric results reported in Panel 2 of Table 5 reveal that the reported spillover effects remain negative for all assets analysed during the MER sample. However, the average size of UMP spillover effects on bond yields and exchange rates is attenuated after the introduction of the MER. In particular, bilateral exchange rates no longer respond significantly to foreign UMP announcements. In contrast, the Swiss stock price index is more strongly affected by foreign UMPs after the MER introduction, and the effect is more significant. However, and importantly, for all assets considered, F-tests do not allow the rejection of the null of equality of the "before"-MER and "after"-MER coefficients.

Although they are not statistically different from pre-MER coefficients, the direction of the spillover effects observed during the MER period suggests that the underlying channels of international UMP transmission - portfolio re-balancing and signalling - remain operational. However, ceteris paribus, Swiss bonds and Swiss equities have lost some of their appeal to international investors. One potential explanation is that the CHF is less likely to appreciate and hence investments in Swiss assets provide less expected appreciation-induced valuation gains for foreign investors. Consequently, as observed, bond yields decline relatively less than they did before the MER introduction. ${ }^{49}$

For stocks, the 'loss of attraction' explanation is counterbalanced by the following effect: the negative impact of a currency appreciation on the eexpected earnings of SMI-listed companies should be more contained after the MER introduction because the expected CHF appreciation is less pronounced. Although it is not possible to take a stand ex ante on the net impact of these two counterbalancing effects, our analysis suggests that the 'loss of attraction' tends to outweigh the effect of an improved outlook for earnings in the Swiss case. ${ }^{50}$

in particular, but also (via EURUSD) for the USDCHF - and thus the overall coefficient should underestimate the true effects that would have ensued without any management of the exchange rate.

${ }^{49} \mathrm{It}$ is important to note that this interpretation hinges crucially on the assumption that the average investors risk aversion remains similar before and after the MER introduction. Otherwise, it would be difficult to reconcile the reported estimates with the proposed narrative. For instance, if investors become more risk averse, we would expect Swiss bonds to become relatively more attractive and their yields to fall more pronouncedly, given the role of Swiss bonds as safe assets.

${ }^{50}$ In fact, the 'loss of attraction' argument may be most relevant for risky Swiss assets as they do not provide any 


\subsection{Spillover asymmetry}

The average effects reported thus far do not account for the observation that certain UMP announcements surprise markets positively whereas others are seen as a disappointment. Hence, results based on the average extent of surprise only tell part of the story. In this section, we discuss whether UMP spillover effects on Swiss asset prices differ between positively and negatively surprising announcements, as suggested in the analysis of Glick and Leduc (2012) with respect to other advanced economies. The question of asymmetric effects has two components: first, it is a question of whether the sign of the spillover effects differs between the two subgroups of announcements. Second, it is a question of whether the strength of the corresponding spillovers differs between positively and negatively surprising announcements.

To address these two questions, we interact the baseline explanatory variable $\Delta s_{t} d_{t}$ with a dummy for "positive surprise" $\left(d_{t, \Delta s_{t}>0}\right)$ and a dummy for "negative surprise" $\left(d_{t, \Delta s_{t}<0}\right)$. The first dummy takes the value of 1 if the surprise measure is positive, whereas the second dummy is set to 1 if the measure yields a negative value. ${ }^{51}$

\section{$<$ Table 6 about here $>$}

Summary statistics provided in Panels 1a and 1b of Table 6 imply that examining restrictive and expansionary announcements separately is worthwhile. Taking the descriptives at face value, positive surprises induce a fall in bond yields and equity prices and induce the CHF to appreciate. In contrast, negative surprises push bond yields and equity prices higher and induce only very contained appreciation of the CHF. In absolute terms, the unconditional means suggest that negative surprises have a more muted impact on all Swiss assets analysed.

To check whether the signs of spillover effects differs, we interact the absolute value of the explanatory variable of interest with two dummies for positive and negative surprises. In line with the results in Glick and Leduc (2012) for other advanced economies, Panel 2 of Table 6 indicates that Swiss equity prices and bond yields react negatively to positive surprises and positively to negative surprises and that the EURCHF appreciates in the former case and depreciates in the latter. The USDCHF depreciates in the case of positive surprises but shows no significant reaction to negative surprises. F-tests show that the difference between the coefficients are indeed significant.

From a policy perspective, it is not only crucial to understand whether announcement effects differ in direction but also to know whether the size of the spillovers differs between positive and negative surprises. Therefore, we compare the coefficients from an estimation based on the the interaction of the dummies with the surprise measure as such, $\Delta s_{t} d_{t}$, not on its absolute values. The corresponding results reported in Panel 3 of Table 6 suggest that the SMI and all bond yields considered respond more strongly to announcements that do not meet the expected degree of expansion, whereas the opposite holds for the EURCHF and USDCHF. ${ }^{52}$ F-tests imply

specific characteristics that would make them more valuable compared to foreign risky assets. Swiss government bonds may still provide value to investors as safe assets, even without any expected appreciation gains.

${ }^{51}$ Recall for interpretation purposes that in this classification, positive announcements are perceived as more expansionary and negative announcements are perceived as more restrictive relative to expectations.

${ }^{52}$ Note for purposes of interpreting the coefficient of the interaction with the negative surprise dummy that a negative value indicates a positive asset price change because it implies the multiplication of two negative values (a negative coefficient times a negative value of the surprise measure). 
that the long-term yields of both Swiss government and Swiss corporate bonds, as well as the USDCHF, are more strongly affected by negative surprises than by positive surprises, whereas the impacts on Swiss stock prices and the EURCHF do not significantly differ in terms of size.

The difference-in-size result contrasts markedly with the conclusion of Glick and Leduc that in a number of advanced economies, the spillover effects on asset prices induced by UMP announcements by the Fed and BoE are more important for positive monetary surprises than for negative surprises. This discrepancy can be attributed to various reasons. Glick and Leduc seem to draw their conclusion based on a set-up that allows for assessing the equality of coefficients in general but not the equality of the size of the estimated effects. Moreover, although the general estimation set-up is similar, crucial details differ in the specification and data base used. Most importantly in this regard, Glick and Leduc focus on the Feds LSAP programmes and BoEs APP, relying only on 15 announcements in total and a commensurately smaller number of negatively and positively surprising announcements.

\subsection{Spillovers along the Swiss yield curve}

This section assesses the impact of foreign UMP announcements on Swiss government bond yields more thoroughly by extending the set of bonds examined along the maturity spectrum covering maturities of two, three, five, seven, nine, and ten years. ${ }^{53}$

$$
<\text { Table } 7 \text { about here }>
$$

The estimation results reported in Table 7 are again based on equation (1) and indicate that the impact of foreign UMP announcements on Swiss government bond yields increases with maturity until approximately 10 years. All estimated coefficients point to a dampening effect of foreign UMPs on yields and are highly significant. ${ }^{54}$

Overall, these findings are in line with intuition. Combining the result that the effect on Swiss bond yield is largest at 7-10 year maturities with the fact that foreign bond purchase programmes focus predominately on precisely those maturities supports the view that Swiss government bonds are seen as close substitutes for foreign government bonds. This reasoning in turn lends support to the interpretation that an international portfolio balance channel is important to an explanation of the transmission of foreign monetary policy shocks to the Swiss yield curve, whereas bonds at different maturities within Switzerland seem to be imperfect substitutes.

Taking a more granular look, Figure 1 suggests that the MER introduction dampened the spillover effect along the entire yield curve and that negatively surprising announcements exert a stronger effect than positive surprises on yields - the latter result being particularly relevant at 7 to 10 year maturities. ${ }^{55}$ In the figure, the upper row of panels depicts the unconditional average yield changes on event days for the respective group of announcements and the lower

\footnotetext{
${ }^{53}$ We use generic ("benchmark") government bond yield series derived from Bloomberg, which does not provide trade volumes. By using these data, we assume that bonds are actually traded and that volumes - and therefore precision - are comparable. Qualitatively, the results are similar when using yield changes derived from an internal term-structure model calculated based on Swiss Government bond data.

${ }^{54}$ Note that the number of observations is similar for all bonds. For the 30y bonds, several missing values are reported primarily at the beginning of the sample. The results are qualitatively unchanged in an analysis based on a 'balanced' sample of events (i.e., if the number of observations is balanced across maturities).

${ }^{55}$ The figures are based on group-wise analyses equivalent to those conducted in sections 6.2 and 6.3.
} 
row depicts the estimated coefficients obtained by the corresponding least squares regressions. For all yields considered, the reported coefficients are smaller in absolute values in the sample that considers UMPs since the MER introduction. However, F-tests do not allow us to reject the null of equality between pre- and post-MER announcement coefficients for any maturity. Regarding the question of spillover asymmetry, the reported coefficients indicate, as they did in section 6.3 above, that the sign of the spillover differs between positive and negative surprises for yields at all maturities considered. Corresponding tests for asymmetry in the strength of spillover effects suggest, as above, that longer-term yields (7y to 10y) are slightly more affected by negative surprises than by positive surprises.

$$
<\text { Figure } 1 \text { about here }>
$$

\section{Robustness}

The baseline results discussed in section 6 are robust to a broad range of checks, including alternative choices of the event set, the policy surprise proxy, control variables, and the length of the sample and of the measurement window, as well as to alternative specifications of the econometric set-up.

\subsection{Event set}

The narrative approach applied to identify monetary policy statements as announcements containing UMP news, and thus the inclusion of monetary policy statements in our baseline event set, is by its very nature prone to misinterpretation and thus to the risk of missing additional relevant statements. Therefore, a first set of robustness checks focuses on the question of whether the results are sensitive to alternative choices of the event set.

Inclusion of all monetary policy announcements during the crisis period. Following Rogers et al. (2014) and Diez and Presno (2013), we conduct the baseline regression exercise using an event set that contains all monetary policy statements between 2008 and the end of 2014, for a total of 379 announcements, including several instances of policy rate changes. The results of this exercise, reported in Table 8, indicate that the main results reported above are robust to the inclusion of this broader set of policy announcements for all assets considered. One key difference concerns the effect on bilateral exchange rates, particularly the impact of ECB and BoE events on the USDCHF. As discussed in the main results section, the exchange rate coefficients should be interpreted with caution due to possible indirect effects through currency triangles.

$$
<\text { Table } 8 \text { about here }>
$$

Exclusion of BoJ Events. Another important issue pertains to the low variability in the surprise measure for Japan, which indicates that our proxy may be unreliable in this case and thus the inclusion of BoJ events may have detrimental effects on the statistical significance of our estimates. However, excluding all BoJ announcements from the event set does not materially alter either the point estimates or their statistical significance. Moreover, excluding the BoJ events comes at the cost of substantially reducing the total number of events. As shown in the 
next section, a less intrusive approach to address issues related to the reliability and availability of Japanese government bond futures data is to rely on alternative surprise measures.

\subsection{Surprise measure}

As discussed in section 5, the baseline policy surprise measure used in this study is subject to measurement issues and reliability questions. This issue calls for a critical assessment of the robustness of our estimates against alternative measures of the extent of market surprise. We report three different checks here: We rely, first, on the change in domestic 10y government bond yields on announcement days in the economy of announcement origin; second, on the change in the spread between Italian and German long-term bond yields as an alternative to the baseline measure of ECB surprise; and third, on a measure that accounts for the effect of indirect spillovers through third countries. ${ }^{56}$

Long-term (10y) government bond yields. UMPs focus directly on influencing longer-term bond yields domestically. Hence, long-term bond yields represent an intuitive choice of policy indicator in the UMP era. Assuming information efficiency, spot prices (or, equivalently, current yields) should change in cases of news only. ${ }^{57}$ An increase in yield on an UMP announcement day can thus be read as indicative of a negative UMP surprise, and vice versa. Estimates indicate that a positively surprising shock - a fall in the domestic bond yield - induces a fall in the SMI and the Swiss 10y yield and a depreciation of the USD against the CHF, thus confirming the results obtained in the baseline exercise in qualitative terms. ${ }^{58}$ On a per-central-bank basis, the baseline results are consistently confirmed for Fed, ECB and UK announcements individually. For the BoJ, the use of government bond yield changes as a proxy for market surprise indicates that BoJ announcements do not exert significant effects on Swiss equities. Given the relatively weak economic and financial links between these two countries, this result is more in line with intuition than the baseline and is a further indication that prudence is warranted with respect to the reliability of the Japanese government bond futures series as a market-based surprise proxy.

Spread between Italian and German bond yields. Due to the lack of Euro area-wide bonds, we use the change in 10y German Bund futures as a proxy for measuring the surprise in ECB policy announcements. In general, situations in which this measure does not indicate the true direction of ECB surprise are conceivable. To circumvent related problems, Rogers et al. (2014) rely instead on the change in the spread between yields on Italian and German 10y government bonds, with a lower spread indicating a positively surprising policy announcement. However, using this spread as an explanatory variable, we do not find any significant spillovers on Swiss assets induced by ECB events. This result is similar to the cross-border effects reported in Rogers et al. (2014), indicating that ECB announcements do not lead to relevant effects on

\footnotetext{
${ }^{56}$ Further alternatives include adapting the baseline surprise measure by considering the principal component derived from a factor decomposition of bond yields or of bond futures at different maturities, as in Chen et al. (2014) and Wright (2012).

${ }^{57}$ The high correlation of local government bond yields and the local surprise measure on announcement days as reported in section 5 support this assumption.

${ }^{58}$ Quantitatively, the obtained coefficients differ from the baseline estimation. This difference is due to the fact that in the sample considered here, a one-standard-deviation increase in the baseline surprise measure reflects a decline of approximately $6 \mathrm{bp}$ in the corresponding long-term bond yield. Hence, coefficients are approximately 6 times smaller in this robustness exercise.
} 
bond yields in the US, Japan and France and lead to only a small increase in UK bond yields.

These results likely reflect the fact that most ECB announcements in our event set aim to ease financial conditions in periphery EMU member states, i.e., they are focused on reducing the risk of financial instability or of a collapse of the Euro itself. If such announcements are positively surprising, as indicated by a reduced spread, they tend to foster financial market confidence globally, inducing safe assets to be less in demand and hence causing their prices to fall. ${ }^{59}$ At the same time, to the extent that the ECB announcements are fundamentally expansionary, they induce global asset prices - including the prices of relatively safe assets - to increase through portfolio balance and liquidity channels. Therefore, the net effect of such announcements on relatively safe assets is unclear.

A decline in the prices of relatively safe assets in response to an announcement targeted at easing financial conditions can thus have one of two causes: either the announcement indeed leads to improved market sentiment, or it is in fact less expansionary than expected. In the first case, a declining spread correctly indicates a positive surprise, whereas in the second case, it does not. Hence, for non-EA-periphery assets, the spread is not an unambiguous measure of the direction of surprise linked to ECB announcements. Thus, to gauge the announcement effect of ECB UMPs on relatively safe assets (such as Swiss assets), it is more appropriate to rely on a surprise measure that is derived from the reaction of a relatively safe euro-denominated asset, such as German long-term government bonds.

Direct vs indirect spillovers. Although our estimates hint at significant effects of UMP announcements, we cannot guarantee that these estimates depict a direct impact on Swiss asset prices exclusively from the origin country. The indirect effects of foreign policy announcements through their impact on asset prices in a third country could possibly dampen or magnify the bilateral effects on Swiss assets, because policy shocks may induce asset price co-movements around the world. The possibility of indirect effects potentially hampers the measurement of the true size of the cross-border asset price effects of monetary policy. To account for this possibility, we use an alternative measure of surprise that comprises the sum of changes in long-term government bond futures in all four foreign economies considered. For instance, on a BoE event day, we consider not only the change in value of the Gilt future but also the changes in the Bund future, Treasury future and Japanese long-term bond future. This process is conducted for each event day accordingly, and the resulting sum of surprise series is used as an explanatory variable in the regression.

Summing all four foreign surprise measures on any UMP announcement day in this manner that is, assuming that one event drives changes in futures in all four foreign economies - broadly confirms the baseline results. More specifically, using this sum of surprise measure returns coefficient values that are 2 to 3 times lower than those in the baseline analysis. The smaller size of the coefficients is related to the fact that the individual surprises are positively correlated, particularly on UMP announcement days, and hence the sum-of-surprise measure is larger than the individual surprise measure, on average. This allows us to interpret the size of the baseline

\footnotetext{
${ }^{59}$ This holds, for instance, for the Whatever it takes (WIT) statement by ECB president Mario Draghi in July 2012. In response to this announcement, 10y German bond yields increased, whereas Italian and other periphery country bond yields dropped. For Swiss assets, which tend to be seen as relatively safe, we observe price decreases in response to the WIT statement.
} 
results as an upper bound and the size of the sum-of-surprise-based estimates as a lower bound of the average spillover effect of foreign UMP announcements on Swiss asset prices.

$$
<\text { Table } 9 \text { about here }>
$$

\subsection{Specification and controls}

Measurement window. The optimal choice of the length of the measurement window is a question of judgement based on the trade-off between mis-measuring due to initial market overreaction and mis-measuring due to noise from other news during the event window (as discussed in section 3). The estimations of the effect of monetary policy surprises on Swiss asset prices based on one-day asset price changes can be repeated using a two-day window. ${ }^{60}$ The coefficients tend to be larger than in the one-day window, particularly for bond yields and the USDCHF, suggesting that markets need a prolonged period of time to fully digest the UMP news.

Alternative controls. No important impact is observed on the estimated size of spillover effects on Swiss asset prices induced by foreign UMP announcements if the change in VIX is replaced by a change in the MOVE, VIX level or an SMI volatility measure; the correlation between the S\&P500 and the SMI is controlled for; or a measure of general economic surprise in Switzerland - the Swiss series of the Citigroup economic surprise index - is added to the regression.

\section{Concluding remarks}

This study indicates that UMP announcements by major central banks since 2008 have substantial spillover effects on asset prices in Switzerland. Specifically, expansionary foreign UMP announcements induce decreases in Swiss bond yields and Swiss equity prices and cause the CHF to appreciate on the day of the announcement. An expansionary UMP shock equivalent to a 25-basis-point decline in local long-term bond yields induces an approximately 6-basis-point decrease in Swiss long-term government bond yields, a 4.5-basis-point decrease in long-term corporate bond yields, a 1-percentage-point decrease in the SMI, an approximately 0.6-percentagepoint appreciation of the CHF against the EUR and an approximately 0.9-percentage-point appreciation of the CHF against the USD. Qualitatively, these estimates of spillovers to Swiss assets corroborate the results regarding cross-border effects of UMPs on asset prices reported by Glick and Leduc (2012), Neely (2015) (selected advanced), Diez and Presno (2013) (bilateral and effective USD effect), Chen et al. (2012b) (Asian emerging markets), and Fratzscher et al. (2013) (advanced and emerging economies as groups).

Four extensions provide additional insights. First, the degree of economic and financial linkages matter substantially. UMPs announced by the ECB have the greatest impact on Swiss asset prices. In particular, bilateral exchange rates respond more strongly to announcements of corresponding central banks. Second, in contrast to Glick and Leduc (2012), our results suggest that the size of spillover effects does not differ materially between negatively and positively surprising announcements. Third, using the implementation of the minimum exchange rate policy, we

\footnotetext{
${ }^{60}$ The two-day change is measured as the difference between the end-of-day value on the day after the announcement and the end-of-day value of the corresponding asset price on the day before the announcement.
} 
show that even decisive domestic policy action only partially mitigates the cross-border spillover effects of foreign UMP announcements. Fourth, a more granular bond market analysis suggests that Swiss 10y government bonds are fairly close substitutes for foreign long-term government bonds. Although substantial, the degree of substitutability is weaker for long-term corporate bonds and particularly for government bonds of shorter maturity.

The estimated spillover effects are important from an economic perspective: on the day of their announcement, the unexpected part of foreign UMPs is responsible for large parts of the observed changes in Swiss asset prices. Our estimates suggest that on UMP event days, policy-induced spillovers are by and large responsible for the cumulative decline in Swiss longerterm government and corporate bond yields, whereas they account for approximately $60 \%$ of the cumulative decline in the Swiss Market Index and for approximately 35\% and $40 \%$ of the appreciation of the CHF against the Euro and the USD, respectively. ${ }^{61}$

With respect to spillover channels, our results can be interpreted tentatively as follows: a portfolio re-balancing channel is important for explaining spillovers to Swiss bond yields, in line with evidence provided by Bauer and Neely (2014). For Swiss equity prices, (negative) international signalling and exchange rate effects outweigh the price-boosting effect of more abundant global liquidity and lower (global) discount rates.

The results must be interpreted with appropriate prudence. First, the approach applied does not allow for a thorough analysis of the contribution of individual transmission channels to the overall asset price effect. A second note of caution concerns the role of market functioning and its potential impact on the reported results. The estimated effects of UMP statements are based on observations in a period during which markets may not have functioned fully or properly. Applying similar policies may not be as effective in more normal times. Third, the jury is still out on the best approach to capture the surprise part of an unconventional monetary policy announcement.

Extensions left for future research include a comparison of the size of the spillover effects reported here to the size of asset price effects induced by domestic UMP announcements. Similarly, it would be fruitful to assess whether UMP spillover effects differ (in terms of size and channels) from spillovers induced by conventional monetary policy announcements, i.e., interest rate policies, and to compare the spillover effects of movements in foreign long-term bond futures on event days with their effects on non-event days. Broadening the scope of the analysis by including other advanced small open countries would also be worthwhile. In terms of specification, additional insights could be gained in an exercise that allows for actual asset purchases, or deeds, to have effects on asset prices. Finally, the tentative interpretation of the spillover channels at work based on our results warrants a formal analysis.

\footnotetext{
${ }^{61}$ To obtain these values, we compare the predicted spillover impact as revealed by our estimates with the cumulative change in the corresponding Swiss asset price as observed on announcement days.
} 
TABLE 1: Summary statistics for surprise measure

Event days (90 obs.)

\begin{tabular}{lcccc}
\hline & US & EU & UK & JP \\
\hline Mean & 0.18 & 0.13 & 0.15 & 0.23 \\
Standard dev. & 1.69 & 1.34 & 1.10 & 1.05 \\
Events of correspond. & central bank \\
\hline Mean & 0.77 & -0.25 & 0.19 & 0.35 \\
Standard dev. & 2.06 & 1.43 & 1.50 & 0.90 \\
Non-event days & $(1656$ & obs.) & & \\
\hline Mean & 0.01 & 0.04 & -0.01 & 0.01 \\
Standard dev. & 0.94 & 0.98 & 1.00 & 0.98 \\
\hline
\end{tabular}

The UMP event set comprises 97 statements (34 Fed, $20 \mathrm{ECB}, 16 \mathrm{BOE}$ and $27 \mathrm{BoJ}$ ), 14 of which were announced pairwisely on the same day. This event set yields a total of 90 days with at least one UMP announcement.

TABLE 2: Correlation of surprises with local bond yields

\begin{tabular}{lcccc}
\hline Events & US & EU & UK & JP \\
\hline Events of corr. CB & -0.97 & -0.98 & -0.99 & -0.79 \\
Non-event days & -0.85 & -0.91 & -0.72 & -0.63 \\
\hline
\end{tabular}

This table shows the correlation of local surprises (baseline surprises) with local government bond yields. For example, on days with a Fed announcement, the first row in column US prints the correlation coefficient of the change in U.S. $10 \mathrm{y}$ government bond yields and the standardised change in the U.S. long-term bond futures price. 
TABLE 3: Spillover effects of UMP announcements

Panel 1a: Asset price summary statistics on event days (90 obs.)

\begin{tabular}{lccccc}
\hline & SMI & Euro & USD & GB 10y & CP 7-10y \\
\hline Mean & -0.18 & -0.16 & -0.14 & -0.42 & -0.33 \\
Standard dev. & 1.59 & 0.60 & 0.97 & 4.32 & 3.65
\end{tabular}

Panel 1b: Asset price summary statistics on non-event days

\begin{tabular}{lrrrrr}
\hline Mean & 0.02 & -0.01 & 0.00 & -0.13 & -0.15 \\
Standard dev. & 1.22 & 0.52 & 0.73 & 3.52 & 3.13
\end{tabular}

Panel 2: Regression, without surprise

\begin{tabular}{|c|c|c|c|c|c|}
\hline Constant & $\begin{array}{c}0.04 \\
(0.199)\end{array}$ & $\begin{array}{c}-0.01 \\
(0.453)\end{array}$ & $\begin{array}{c}0.01 \\
(0.762)\end{array}$ & $\begin{array}{l}-0.13 \\
(0.134)\end{array}$ & $\begin{array}{l}-0.14 \dagger \\
(0.059)\end{array}$ \\
\hline Event Dummy & $\begin{array}{c}-0.24 \\
(0.175)\end{array}$ & $\begin{array}{c}-0.14 \dagger \\
(0.060)\end{array}$ & $\begin{array}{l}-0.24^{*} \\
(0.021)\end{array}$ & $\begin{array}{l}-0.34 \\
(0.457)\end{array}$ & $\begin{array}{c}-0.17 \\
(0.661)\end{array}$ \\
\hline No. Obs. & 1694 & 1763 & 1763 & 1718 & 1688 \\
\hline \multicolumn{6}{|c|}{ Panel 3: Regression, with surprise } \\
\hline Constant & $\begin{array}{c}0.03 \\
(0.287)\end{array}$ & $\begin{array}{c}-0.01 \\
(0.259)\end{array}$ & $\begin{array}{c}-0.00 \\
(0.910)\end{array}$ & $\begin{array}{l}-0.12 \\
(0.159)\end{array}$ & $\begin{array}{l}-0.13 \dagger \\
(0.079)\end{array}$ \\
\hline Surprise & $\begin{array}{c}-0.26^{* *} \\
(0.007)\end{array}$ & $\begin{array}{l}-0.14^{*} \\
(0.017)\end{array}$ & $\begin{array}{c}-0.22^{* *} \\
(0.002)\end{array}$ & $\begin{array}{c}-1.46^{* *} \\
(0.000)\end{array}$ & $\begin{array}{c}-1.13^{* *} \\
(0.000)\end{array}$ \\
\hline VIX & $\begin{array}{c}-0.03^{* *} \\
(0.000)\end{array}$ & $\begin{array}{c}0.00 \dagger \\
(0.094)\end{array}$ & $\begin{array}{c}-0.00 \\
(0.520)\end{array}$ & $\begin{array}{c}0.03 \dagger \\
(0.054)\end{array}$ & $\begin{array}{l}0.04^{* *} \\
(0.002)\end{array}$ \\
\hline US Gov bonds & $\begin{array}{l}0.02^{* *} \\
(0.003)\end{array}$ & $\begin{array}{c}0.00 \\
(0.629)\end{array}$ & $\begin{array}{c}-0.00 \\
(0.879)\end{array}$ & $\begin{array}{l}0.15^{* *} \\
(0.000)\end{array}$ & $\begin{array}{l}0.14^{* *} \\
(0.000)\end{array}$ \\
\hline Lagged dep. & $\begin{array}{c}-0.08 \\
(0.225)\end{array}$ & $\begin{array}{c}0.04 \\
(0.361)\end{array}$ & $\begin{array}{c}-0.01 \\
(0.642)\end{array}$ & $\begin{array}{l}-0.06 \dagger \\
(0.093)\end{array}$ & $\begin{array}{c}0.01 \\
(0.814)\end{array}$ \\
\hline No. Obs. & 1694 & 1741 & 1741 & 1706 & 1688 \\
\hline
\end{tabular}

This table reports asset price summary statistics (Panels 1a and 1b) and regression results excluding (Panel 2) and including (Panel 3) our baseline surprise measure. Significance levels for regressions are $1 \%(* *)$, $5 \%(*)$, and $10 \%(\dagger)$. Values in parentheses represent p-values. Control variables are omitted for Panel 2.

Dependent variables reported are the Swiss equity market index (SMI), EURCHF (Euro), USDCHF (USD), Swiss government bonds with maturity 10y (GB 10y) and Swiss corporate bonds with maturity between 7 and 10y (CP 7-10y). Asset prices enter as daily changes, measured either in percentage points (SMI, exchange rates) or in basis points (bond yields). The surprise is measured in units of standard deviations of the daily change in the longer-term government bond future.

The sample runs from 1 January 2008 to 31 December 2014 and contains 90 days on which at least one of the central banks considered released an UMP statement. The total number of observations for individual assets differs due to missing values on non-event days. 
TABLE 4: Spillovers by announcing central bank

\begin{tabular}{cccccc}
\hline & SMI & Euro & USD & GB 10y & CP 7-10y \\
\hline Constant & 0.03 & -0.01 & -0.00 & -0.12 & $-0.14 \dagger$ \\
& $(0.345)$ & $(0.228)$ & $(0.964)$ & $(0.141)$ & $(0.066)$ \\
US events & -0.11 & $-0.16 \dagger$ & $-0.38^{* *}$ & $-1.28^{* *}$ & $-0.96^{* *}$ \\
& $(0.225)$ & $(0.052)$ & $(0.000)$ & $(0.000)$ & $(0.000)$ \\
EU events & $-0.84^{* *}$ & $-0.25^{*}$ & -0.02 & $-2.06^{* *}$ & $-1.87^{* *}$ \\
& $(0.005)$ & $(0.047)$ & $(0.792)$ & $(0.000)$ & $(0.000)$ \\
UK events & -0.17 & -0.06 & $0.09 \dagger$ & $-1.72^{* *}$ & $-1.17^{* *}$ \\
& $(0.333)$ & $(0.333)$ & $(0.081)$ & $(0.001)$ & $(0.000)$ \\
JP events & $-0.40^{*}$ & 0.05 & -0.03 & $-1.16^{*}$ & $-0.84 \dagger$ \\
& $(0.014)$ & $(0.578)$ & $(0.866)$ & $(0.044)$ & $(0.081)$ \\
No. Obs. & 1694 & 1741 & 1741 & 1706 & 1688 \\
\hline
\end{tabular}

This table reports regression results using our baseline surprise measure. The underlying event set is grouped by announcing central bank, yielding $34 \mathrm{Fed}, 20 \mathrm{ECB}, 16 \mathrm{BoE}$ and $27 \mathrm{BoJ}$ observations.

For values in parentheses, significance levels, and units, see Table 3. Control variables omitted.

TABle 5: Spillovers and the minimum exchange rate policy

Panel 1a: Asset price sum. stats on pre-MER event days (47 obs.)

\begin{tabular}{lccccc}
\hline & SMI & Euro & USD & GB 10y & CP 7-10y \\
\hline Mean & -0.53 & -0.31 & -0.31 & -0.71 & -0.65 \\
Standard dev. & 1.89 & 0.77 & 1.11 & 5.05 & 4.38 \\
Panel 1b: Asset price & sum. stats & on event & days & during MER & (43 obs.) \\
\hline Mean & 0.25 & 0.01 & 0.04 & -0.08 & 0.02 \\
Standard dev. & 1.04 & 0.18 & 0.73 & 3.16 & 2.56 \\
Panel 2: Spillovers before and & after MER & implementation & \\
\hline Constant & 0.03 & -0.01 & -0.00 & -0.12 & $-0.13 \dagger$ \\
Surprise before MER & $-0.290)$ & $(0.268)$ & $(0.933)$ & $(0.162)$ & $(0.080)$ \\
& $(0.041)$ & $-0.17^{*}$ & $-0.27^{* *}$ & $-1.52^{* *}$ & $-1.14^{* *}$ \\
Surprise after MER & $-0.33^{* *}$ & $-0.05 \dagger$ & $(0.000)$ & $(0.000)$ & $(0.000)$ \\
& $(0.000)$ & $(0.065)$ & $(0.629)$ & $-1.27^{* *}$ & $-1.09^{* *}$ \\
& $0.000)$ & $(0.000)$ \\
\hline F-test & 0.33 & 1.91 & $3.50 \dagger$ & 0.54 & 0.03 \\
& $(0.56)$ & $(0.17)$ & $(0.06)$ & $(0.46)$ & $(0.87)$ \\
No. Obs. & 1694 & 1741 & 1741 & 1706 & 1688 \\
\hline
\end{tabular}

This table reports asset price summary statistics (Panels $1 \mathrm{a}$ and $1 \mathrm{~b}$ ) and regression results using our baseline surprise measure (Panel 2). The underlying event set is divided by the implementation of the minimum exchange rate by the SNB on 6 September, 2011.

For values in parentheses, significance levels, and units see Table 3. Control variables omitted. The F-test tests the null of equality of the coefficients for the surprise variable before and after the minimum exchange rate. 
TABLE 6: Spillover asymmetry

Panel 1a: Asset price sum. stats for expansionary surprises (51 obs.)

\begin{tabular}{lccccc}
\hline & SMI & Euro & USD & GB 10y & CP 7-10y \\
\hline Mean & -0.43 & -0.26 & -0.24 & -2.51 & -2.22 \\
Standard dev. & 1.32 & 0.65 & 1.05 & 3.38 & 2.90 \\
Panel 1b: Asset price sum. & stats for & restrictive & surprises & (38 obs.) \\
\hline Mean & 0.17 & -0.02 & -0.04 & 2.39 & 2.22 \\
Standard dev. & 1.84 & 0.47 & 0.81 & 3.75 & 2.99 \\
& & & & & \\
Panel 2: Spillover & asymmetry & (sign, & using abs. & surprise) & \\
\hline Constant & 0.02 & -0.01 & 0.01 & $-0.14 \dagger$ & $-0.15^{*}$ \\
& $(0.418)$ & $(0.298)$ & $(0.668)$ & $(0.096)$ & $(0.050)$ \\
Positive Surprise & $-0.20^{*}$ & $-0.15 \dagger$ & $-0.30^{* *}$ & $-1.27^{* *}$ & $-0.98^{* *}$ \\
& $(0.036)$ & $(0.055)$ & $(0.000)$ & $(0.000)$ & $(0.000)$ \\
Negative Surprise & $0.48^{*}$ & $0.11^{* *}$ & -0.07 & $2.13^{* *}$ & $1.63^{* *}$ \\
& $(0.016)$ & $(0.002)$ & $(0.439)$ & $(0.000)$ & $(0.000)$ \\
\hline F-test & $9.63^{* *}$ & $9.56^{* *}$ & $4.31 \dagger$ & $65.70^{* *}$ & $57.33^{* *}$ \\
& $(0.00)$ & $(0.00)$ & $(0.04)$ & $(0.00)$ & $(0.00)$ \\
No. Obs. & 1694 & 1741 & 1741 & 1706 & 1688 \\
Panel 3: Spillover & asymmetry & $($ size) & & & \\
\hline Constant & 0.02 & -0.01 & 0.01 & $-0.14 \dagger$ & $-0.15^{*}$ \\
Positive Surprise & $(0.418)$ & $(0.298)$ & $(0.668)$ & $(0.096)$ & $(0.050)$ \\
Negative Surprise & $-0.20^{*}$ & $-0.15 \dagger$ & $-0.30^{* *}$ & $-1.27^{* *}$ & $-0.98^{* *}$ \\
& $(0.036)$ & $(0.055)$ & $(0.000)$ & $(0.000)$ & $(0.000)$ \\
& $(0.016)$ & $(0.002)$ & $(0.439)$ & $(0.000)$ & $(0.000)$ \\
\hline F-test & 1.55 & 0.15 & $10.99^{* *}$ & $4.15 \dagger$ & $3.49 \dagger$ \\
No. Obs. & $(0.21)$ & $(0.70)$ & $(0.00)$ & $(0.04)$ & $(0.06)$ \\
\hline & 1694 & 1741 & 1741 & 1706 & 1688 \\
\hline
\end{tabular}

This table reports asset price summary statistics (Panels $1 \mathrm{a}$ and $1 \mathrm{~b}$ ) and regression results using our baseline surprise measure (Panels 2 and 3). The underlying event set is divided by the corresponding sign of the surprise measure, which is classified as expansionary if positive and restrictive if negative.

For values in parentheses, significance levels, and units see Table 3. Control variables omitted. The F-tests test the null of equality of the coefficients for positively and negatively surprising announcements.

TABLE 7: Spillover effects along the yield curve

\begin{tabular}{lccccccc}
\hline & GB 2y & GB 3y & GB 4y & GB 5y & GB 7y & GB 9y & GB 10y \\
\hline Constant & -0.08 & -0.10 & -0.11 & -0.12 & -0.12 & -0.12 & -0.12 \\
& $(0.463)$ & $(0.231)$ & $(0.174)$ & $(0.143)$ & $(0.145)$ & $(0.167)$ & $(0.159)$ \\
Surprise & $-0.69^{*}$ & $-0.82^{*}$ & $-1.02^{* *}$ & $-1.15^{* *}$ & $-1.16^{* *}$ & $-1.55^{* *}$ & $-1.46^{* *}$ \\
& $(0.030)$ & $(0.011)$ & $(0.000)$ & $(0.000)$ & $(0.000)$ & $(0.000)$ & $(0.000)$ \\
No. Obs. & 1707 & 1662 & 1707 & 1708 & 1615 & 1663 & 1706 \\
\hline
\end{tabular}

This table reports regression results using our baseline surprise measure. The underlying event set comprises all events.

For values in parentheses, significance levels, and units see Table 3. Control variables omitted. 
TABLE 8: Extended list of announcements

Panel 1: Baseline event set

\begin{tabular}{|c|c|c|c|c|c|}
\hline & SMI & Euro & USD & GB 10y & CP 7-10y \\
\hline Constant & $\begin{array}{c}0.03 \\
(0.345)\end{array}$ & $\begin{array}{c}-0.01 \\
(0.228)\end{array}$ & $\begin{array}{c}-0.00 \\
(0.964)\end{array}$ & $\begin{array}{c}-0.12 \\
(0.141)\end{array}$ & $\begin{array}{l}-0.14 \dagger \\
(0.066)\end{array}$ \\
\hline US events & $\begin{array}{l}-0.11 \\
(0.225)\end{array}$ & $\begin{array}{l}-0.16 \dagger \\
(0.052)\end{array}$ & $\begin{array}{c}-0.38^{* *} \\
(0.000)\end{array}$ & $\begin{array}{c}-1.28^{* *} \\
(0.000)\end{array}$ & $\begin{array}{c}-0.96^{* *} \\
(0.000)\end{array}$ \\
\hline EU events & $\begin{array}{c}-0.84^{* *} \\
(0.005)\end{array}$ & $\begin{array}{l}-0.25^{*} \\
(0.047)\end{array}$ & $\begin{array}{c}-0.02 \\
(0.792)\end{array}$ & $\begin{array}{c}-2.06^{* *} \\
(0.000)\end{array}$ & $\begin{array}{c}-1.87^{* *} \\
(0.000)\end{array}$ \\
\hline UK events & $\begin{array}{c}-0.17 \\
(0.333)\end{array}$ & $\begin{array}{l}-0.06 \\
(0.333)\end{array}$ & $\begin{array}{c}0.09 \dagger \\
(0.081)\end{array}$ & $\begin{array}{c}-1.72^{* *} \\
(0.001)\end{array}$ & $\begin{array}{c}-1.17^{* *} \\
(0.000)\end{array}$ \\
\hline JP events & $\begin{array}{l}-0.40^{*} \\
(0.014)\end{array}$ & $\begin{array}{c}0.05 \\
(0.578)\end{array}$ & $\begin{array}{c}-0.03 \\
(0.866)\end{array}$ & $\begin{array}{l}-1.16^{*} \\
(0.044)\end{array}$ & $\begin{array}{l}-0.84 \dagger \\
(0.081)\end{array}$ \\
\hline $\begin{array}{l}\text { No. Obs. } \\
\text { Panel 2: Es }\end{array}$ & $\begin{array}{l}1694 \\
\text { nded er }\end{array}$ & $\begin{array}{l}1741 \\
\text { t set }\end{array}$ & 1741 & 1706 & 1688 \\
\hline Constant & $\begin{array}{c}0.03 \\
(0.394)\end{array}$ & $\begin{array}{c}-0.02 \\
(0.169)\end{array}$ & $\begin{array}{c}-0.00 \\
(0.794)\end{array}$ & $\begin{array}{c}-0.13 \\
(0.118)\end{array}$ & $\begin{array}{l}-0.14 \dagger \\
(0.057)\end{array}$ \\
\hline US events & $\begin{array}{c}-0.05 \\
(0.703)\end{array}$ & $\begin{array}{c}-0.11 \\
(0.117)\end{array}$ & $\begin{array}{c}-0.28^{* *} \\
(0.001)\end{array}$ & $\begin{array}{c}-1.57^{* *} \\
(0.000)\end{array}$ & $\begin{array}{c}-1.01^{* *} \\
(0.000)\end{array}$ \\
\hline EU events & $\begin{array}{c}-0.77^{* *} \\
(0.000)\end{array}$ & $\begin{array}{c}-0.25^{* *} \\
(0.002)\end{array}$ & $\begin{array}{c}0.22^{*} \\
(0.015)\end{array}$ & $\begin{array}{c}-1.99 * * \\
(0.000)\end{array}$ & $\begin{array}{c}-1.59^{* *} \\
(0.000)\end{array}$ \\
\hline UK events & $\begin{array}{c}-0.11 \\
(0.321)\end{array}$ & $\begin{array}{c}-0.03 \\
(0.536)\end{array}$ & $\begin{array}{c}-0.07 \\
(0.529)\end{array}$ & $\begin{array}{c}-0.95^{* *} \\
(0.009)\end{array}$ & $\begin{array}{c}-1.28^{* *} \\
(0.000)\end{array}$ \\
\hline JP events & $\begin{array}{l}-0.26 \dagger \\
(0.070)\end{array}$ & $\begin{array}{c}-0.04 \\
(0.473)\end{array}$ & $\begin{array}{c}-0.07 \\
(0.457)\end{array}$ & $\begin{array}{c}-1.26^{* *} \\
(0.001)\end{array}$ & $\begin{array}{c}-1.25^{* *} \\
(0.000)\end{array}$ \\
\hline No. Obs. & 1694 & 1741 & 1741 & 1706 & 1688 \\
\hline
\end{tabular}

Panel 1 of this table repeats the baseline results from Table 4, whereas Panel 2 reports the results of a regression based on the extended event set described in the text. The number of monetary policy announcements in the extended event set amounts to 73 for the Fed, 98 for the ECB, 92 for the BoE, and 104 for the BoJ. See notes to Tables 3 and 4. 
TABLE 9: Direct vs indirect spillovers

Panel 1: Direct spillovers

\begin{tabular}{|c|c|c|c|c|c|}
\hline & SMI & Euro & USD & GB $10 y$ & CP 7-10y \\
\hline \multirow[t]{2}{*}{ Constant } & 0.03 & -0.01 & -0.00 & -0.12 & $-0.14 \dagger$ \\
\hline & $(0.345)$ & $(0.228)$ & $(0.964)$ & $(0.141)$ & $(0.066)$ \\
\hline \multirow[t]{2}{*}{ US events } & -0.11 & $-0.16 \dagger$ & $-0.38^{* *}$ & $-1.28^{* *}$ & $-0.96^{* *}$ \\
\hline & $(0.225)$ & $(0.052)$ & $(0.000)$ & $(0.000)$ & $(0.000)$ \\
\hline \multirow[t]{2}{*}{ EU events } & $-0.84^{* *}$ & $-0.25^{*}$ & -0.02 & $-2.06^{* *}$ & $-1.87^{* *}$ \\
\hline & $(0.005)$ & $(0.047)$ & $(0.792)$ & $(0.000)$ & $(0.000)$ \\
\hline \multirow{2}{*}{ UK events } & -0.17 & -0.06 & $0.09 \dagger$ & $-1.72^{* *}$ & $-1.17^{* *}$ \\
\hline & $(0.333)$ & $(0.333)$ & $(0.081)$ & $(0.001)$ & $(0.000)$ \\
\hline \multirow{2}{*}{ JP events } & $-0.40^{*}$ & 0.05 & -0.03 & $-1.16^{*}$ & $-0.84 \dagger$ \\
\hline & $(0.014)$ & $(0.578)$ & $(0.866)$ & $(0.044)$ & $(0.081)$ \\
\hline No. Obs. & 1694 & 1741 & 1741 & 1706 & 1688 \\
\hline \multicolumn{6}{|c|}{ Panel 2: Indirect spillovers (sum of surprises) } \\
\hline \multirow[t]{2}{*}{ Constant } & 0.03 & -0.02 & -0.00 & -0.12 & $-0.13 \dagger$ \\
\hline & $(0.335)$ & $(0.199)$ & $(0.797)$ & $(0.143)$ & $(0.069)$ \\
\hline \multirow{2}{*}{ US events } & -0.08 & $-0.07^{*}$ & $-0.12^{*}$ & $-0.56^{* *}$ & $-0.46^{* *}$ \\
\hline & $(0.101)$ & $(0.023)$ & $(0.044)$ & $(0.000)$ & $(0.000)$ \\
\hline \multirow[t]{2}{*}{ EU events } & $-0.35^{*}$ & $-0.13^{*}$ & -0.04 & $-0.73^{* *}$ & $-0.80 * *$ \\
\hline & $(0.011)$ & $(0.048)$ & $(0.374)$ & $(0.001)$ & $(0.000)$ \\
\hline \multirow[t]{2}{*}{ UK events } & -0.05 & -0.02 & $0.04 \dagger$ & $-0.64^{*}$ & $-0.37^{* *}$ \\
\hline & $(0.524)$ & $(0.481)$ & $(0.061)$ & $(0.017)$ & $(0.001)$ \\
\hline \multirow[t]{2}{*}{ JP events } & $-0.13^{*}$ & -0.02 & 0.05 & $-0.47 * *$ & $-0.40^{*}$ \\
\hline & $(0.026)$ & $(0.614)$ & $(0.378)$ & $(0.002)$ & $(0.011)$ \\
\hline No. Obs. & 1694 & 1741 & 1741 & 1706 & 1688 \\
\hline
\end{tabular}

Panel 1 of this table repeats the results using the baseline surprise measure, as in Table 4, whereas Panel 2 shows the results based on the sum-of-surprise measure described in the text. See notes to Tables 3 and 4. 
Figure 1: Spillover effects along the yield curve

Baseline

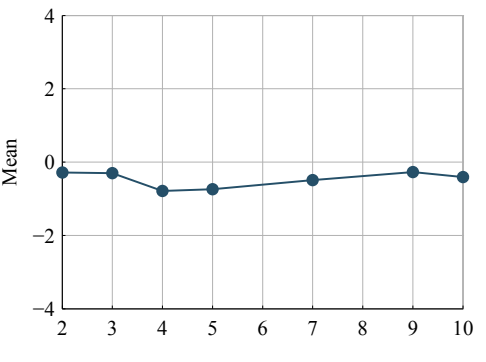

$\rightarrow$ All events

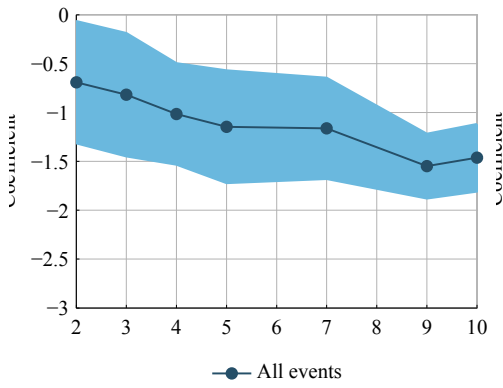

Pre- and Post-MER

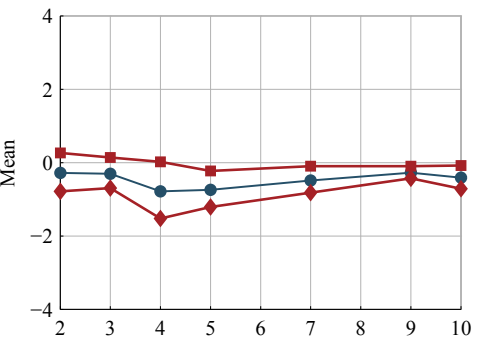

$\rightarrow$ All events $\rightarrow$ Pre-MER $\rightarrow$-MER

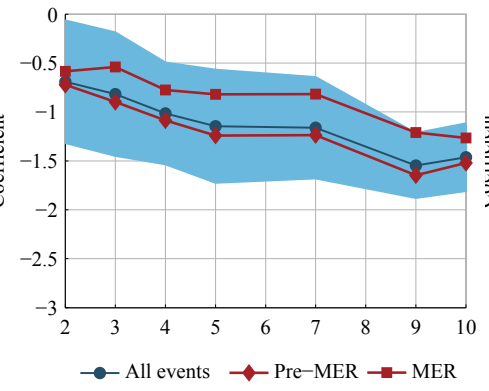

Pos. and Neg. Surprise
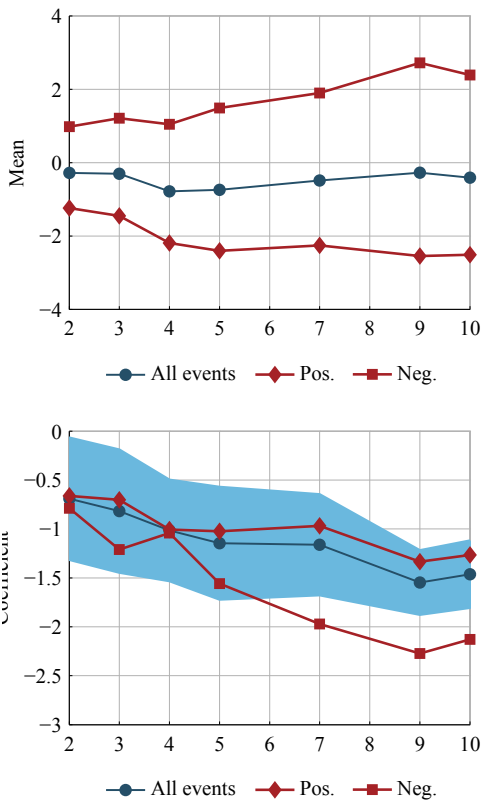

In this figure, the charts in the first row depict the average change (vertical axis) of Swiss government bond yields at different maturities (specified on the horizontal axis in years) on event days and the charts in the second row depict the coefficients of the corresponding regressions using the baseline surprise measure. The charts on the left are based on all foreign UMP announcements (the baseline event set); the charts in the middle separate these announcements into pre- and post- 6 September 2011 (when the SNB announced the minimum exchange rate) samples; and the charts on the right group the announcements by the sign of the surprise measure. Blue shaded areas represent the $95 \%$ confidence bands for the coefficient estimated based on all UMP announcements. 


\section{References}

Ahmed, Shaghil and Andrei Zlate. 2014. Capital flows to emerging market economies: A brave new world? Journal of International Money and Finance 48(PB): 221-248.

Aït-Sahalia, Yacine, Jochen Andritzky, Andreas Jobst, Sylwia Nowak and Natalia Tamirisa. 2012. Market response to policy initiatives during the global financial crisis. Journal of International Economics 87(1): 162-177.

Bauer, Michael D. and Christopher J. Neely. 2014. International channels of the Fed's unconventional monetary policy. Journal of International Money and Finance 44(0): $24-46$.

Bauer, Michael D. and Glenn D. Rudebusch. 2014. The Signaling Channel for Federal Reserve Bond Purchases. International Journal of Central Banking 10(3): 233-289.

Berge, Travis J. and Guangye Cao. 2014. Global effects of U.S. monetary policy: is unconventional policy different? Federal Reserve Bank of Kansas City Economic Review Q I: 5-31.

Cahill, Michael E., Stefania D'Amico, Canlin Li and John S. Sears. 2013. Duration risk versus local supply channel in Treasury yields: evidence from the Federal Reserve's asset purchase announcements. Finance and Economics Discussion Series 2013-35, Board of Governors of the Federal Reserve System (U.S.).

Caruana, Jamie. 2012. International monetary policy interactions: challenges and prospects. Speech held at the CEMLA-SEACEN conference on "The role of central banks in macroeconomic andfinancial stability: the challenges in an uncertain and volatile world", Punta del Este, Uruguay.

Chadha, Jagjit S, Philip Turner and Fabrizio Zampolli. 2013. The interest rate effects of government debt maturity. BIS Working Papers 415, Bank for International Settlements.

Chen, Han, Vasco Cúrdia and Andrea Ferrero. 2012a. The Macroeconomic Effects of Large-scale Asset Purchase Programmes. Economic Journal 122(564): F289-F315.

Chen, Jiaqian, Tommaso Mancini Griffoli and Ratna Sahay. 2014. Spillovers from United States Monetary Policy on Emerging Markets: Different This Time? IMF Working Papers 14/240, International Monetary Fund.

Chen, Qianying, Andrew Filardo, Dong He and Feng Zhu. 2012b. International spillovers of central bank balance sheet policies. In Are central bank balance sheets in Asia too large?, ed. Bank for International Settlements, BIS Papers chapters, volume 66, 220-264. Bank for International Settlements.

Chinn, Menzie D. 2013. Global spillovers and domestic monetary policy. BIS Working Papers 436, Bank for International Settlements.

Christensen, Jens H. E. and Glenn D. Rudebusch. 2012. The Response of Interest Rates to US and UK Quantitative Easing. Economic Journal 122(564): F385-F414.

Cochrane, John Howland. 2001. Asset pricing. Princeton Univ. Press.

Cour-Thimann, Philippine and Bernhard Winkler. 2012. The ECBs non-standard monetary policy measures: the role of institutional factors and financial structure. Oxford Review of Economic Policy 28(4): 765-803. 
Diez, Federico J. and Ignacio Presno. 2013. Domestic and foreign announcements on unconventional monetary policy and exchange rates. Technical report, Federal Reserve Bank of Boston.

Doh, Taeyoung and Michael Connolly. 2013. Has the effect of monetary policy announcements on asset prices changed? Economic Review Q III: 31-65.

Dreher, Axel. 2006. Does globalization affect growth? Evidence from a new index of globalization. Applied Economics 38(10): 1091-1110. Http://globalization.kof.ethz.ch.

Durré, A and H Pill. 2012. Central Bank balance sheets as policy tools. In Are central bank balance sheets in Asia too large?, ed. Bank for International Settlements, BIS Papers chapters, volume 66, 193-213. Bank for International Settlements.

Ehrmann, Michael and Marcel Fratzscher. 2009. Global Financial Transmission of Monetary Policy Shocks. Oxford Bulletin of Economics and Statistics 71(6): 739-759.

Faust, Jon, John H. Rogers, Shing-Yi B. Wang and Jonathan H. Wright. 2007. The highfrequency response of exchange rates and interest rates to macroeconomic announcements. Journal of Monetary Economics 54(4): 1051-1068.

Fawley, Brett W. and Christopher J. Neely. 2013. Four stories of quantitative easing. Review $51-88$.

Fratzscher, Marcel, Marco Lo Duca and Roland Straub. 2013. On the International Spillovers of US Quantitative Easing. Discussion Papers of DIW Berlin 1304, DIW Berlin, German Institute for Economic Research.

Fratzscher, Marcel, Marco Lo Duca and Roland Straub. 2014. ECB Unconventional Monetary Policy Actions: Market Impact, International Spillovers and Transmission Channels. Paper presented at the 15th Jacques Polak Annual Research Conference.

Gagnon, Joseph, Matthew Raskin, Julie Remache and Brian Sack. 2011. The Financial Market Effects of the Federal Reserve's Large-Scale Asset Purchases. International Journal of Central Banking 7(1): 3-43.

Gertler, Mark and Peter Karadi. 2015. Monetary Policy Surprises, Credit Costs, and Economic Activity. American Economic Journal: Macroeconomics 7(1): 44-76.

Glick, Reuven and Sylvain Leduc. 2012. Central bank announcements of asset purchases and the impact on global financial and commodity markets. Journal of International Money and Finance 31(8): 2078-2101.

Glick, Reuven and Sylvain Leduc. 2015. Unconventional monetary policy and the dollar: conventional signs, unconventional magnitudes. Working Paper Series 2015-18, Federal Reserve Bank of San Francisco.

Gürkaynak, Refet S, Brian Sack and Eric Swanson. 2005. Do Actions Speak Louder Than Words? The Response of Asset Prices to Monetary Policy Actions and Statements. International Journal of Central Banking 1(1).

Gürkaynak, Refet S., Brian T. Sack and Eric P. Swanson. 2007. Market-Based Measures of Monetary Policy Expectations. Journal of Business 83 Economic Statistics 25: 201-212.

Gürkaynak, Refet S. and Jonathan H. Wright. 2013. Identification and Inference Using Event Studies. Manchester School 81: 48-65. 
He, Dong and Robert N McCauley. 2013. Transmitting global liquidity to East Asia: policy rates, bond yields, currencies and dollar credit. BIS Working Papers 431, Bank for International Settlements.

IMF. 2013a. Global Impact and Challenges of Unconventional Monetary Policies. IMF Policy Paper.

IMF. 2013b. Spillover report ' Analytical underpinnings and other background. IMF Multilateral Policy Issues Report.

IMF. 2013c. Unconventional monetary policies - recent experiences and prospects. IMF Staff report.

Joyce, Michael A. S., Ana Lasaosa, Ibrahim Stevens and Matthew Tong. 2011. The Financial Market Impact of Quantitative Easing in the United Kingdom. International Journal of Central Banking 7(3): 113-161.

Kiley, Michael T. 2014. The Response of Equity Prices to Movements in Long-Term Interest Rates Associated with Monetary Policy Statements: Before and After the Zero Lower Bound. Journal of Money, Credit and Banking 46(5): 1057-1071.

Krogstrup, Signe, Samuel Reynard and Barbara Sutter. 2012. Liquidity Effects of Quantitative Easing on Long-Term Interest Rates. Working Papers 2012-02, Swiss National Bank.

Krueger, Joel T. and Kenneth N. Kuttner. 1995. The Fed funds futures rate as a predictor of Federal Reserve policy. Working Paper Series, Macroeconomic Issues 95-4, Federal Reserve Bank of Chicago.

Krugman, Paul, Maurice Obstfeld and Marc J. Melitz. 2011. International Economics: Theory E Policy. Prentice Hall, 9 edition.

Kulish, Mariano and Daniel Rees. 2011. The yield curve in a small open economy. Journal of International Economics 85(2): 268 - 279.

Kuttner, Kenneth N. 2001. Monetary policy surprises and interest rates: Evidence from the Fed funds futures market. Journal of Monetary Economics 47(3): 523-544.

Lambert, Frederic and Kenichi Ueda. 2014. The Effects of Unconventional Monetary Policies on Bank Soundness. IMF Working Papers 14/152, International Monetary Fund.

Lenza, Michele, Huw Pill and Lucrezia Reichlin. 2010. Monetary policy in exceptional times. Economic Policy 25(62): 295-339.

Lombardi, Marco Jacopo and Feng Zhu. 2014. A shadow policy rate to calibrate US monetary policy at the zero lower bound. BIS Working Papers 452, Bank for International Settlements.

McLaren, Nick, Ryan N. Banerjee and David Latto. 2014. Using Changes in Auction Maturity Sectors to Help Identify the Impact of QE on Gilt Yields. The Economic Journal 124(576): $453-479$.

Meaning, Jack and Feng Zhu. 2011. The impact of recent central bank asset purchase programmes. BIS Quarterly Review .

Neely, Christopher J. 2015. Unconventional monetary policy had large international effects. Journal of Banking $\& 5$ Finance 52(C): 101-111. 
Obstfeld, Maurice, Jay C. Shambaugh and Alan M. Taylor. 2005. The Trilemma in History: Tradeoffs Among Exchange Rates, Monetary Policies, and Capital Mobility. The Review of Economics and Statistics 87(3): 423-438.

Piazzesi, Monika and Eric T. Swanson. 2008. Futures prices as risk-adjusted forecasts of monetary policy. Journal of Monetary Economics 55(4): 677-691.

Poole, William, Robert H, Rasche and Daniel L. Thornton. 2002. Market anticipations of monetary policy actions. Federal Reserve Bank of St. Louis Review 84(4, July/August): 6594.

Rey, Helene. 2013. Dilemma not trilemma: the global cycle and monetary policy independence. Proceedings - Economic Policy Symposium - Jackson Hole 1-2.

Rigobon, Roberto and Brian Sack. 2003. Measuring the Reaction of Monetary Policy to the Stock Market. The Quarterly Journal of Economics 118(2): 639-669.

Rigobon, Roberto and Brian Sack. 2004. The impact of monetary policy on asset prices. Journal of Monetary Economics 51(8): 1553-1575.

Rogers, John H., Chiara Scotti and Jonathan H. Wright. 2014. Evaluating asset-market effects of unconventional monetary policy: a multi-country review. Economic Policy 29(80): 749-799.

Romer, Christina D. and David H. Romer. 1989. Does Monetary Policy Matter? A New Test in the Spirit of Friedman and Schwartz. In NBER Macroeconomics Annual 1989, Volume 4, NBER Chapters, 121-184. National Bureau of Economic Research, Inc.

Romer, Christina D. and David H. Romer. 2004. A New Measure of Monetary Shocks: Derivation and Implications. American Economic Review 94(4): 1055-1084.

Rosa, Carlo. 2011. The Validity of the Event-study Approach: Evidence from the Impact of the Fed's Monetary Policy on US and Foreign Asset Prices. Economica 78(311): 429-439.

Rosa, Carlo. 2012. How "unconventional" are large-scale asset purchases? The impact of monetary policy on asset prices. Staff Reports 560, Federal Reserve Bank of New York.

Takáts, Elod and Abraham Vela. 2014. International monetary policy transmission. BIS Paper $78 \mathrm{~b}$.

Taylor, John B. 2013. International monetary policy coordination: past, present and future. BIS Working Papers 437, Bank for International Settlements.

White, Halbert. 1980. A Heteroskedasticity-Consistent Covariance Matrix Estimator and a Direct Test for Heteroskedasticity. Econometrica 48(4): 817-38.

Williams, John C. 2014. Monetary Policy at the Zero Lower Bound. Technical report, Hutchins Center on Fiscal and Monetary Policy.

Wright, Jonathan H. 2012. What does Monetary Policy do to Long-term Interest Rates at the Zero Lower Bound? The Economic Journal 122(564): F447-F466.

Wu, Jing Cynthia and Fan Dora Xia. 2014. Measuring the Macroeconomic Impact of Monetary Policy at the Zero Lower Bound. NBER Working Papers 20117, National Bureau of Economic Research, Inc. 


\section{A Data}

All data are taken from Bloomberg. Table 10 provides the comprehensive list of variables and abbreviations used in the empirical analysis, Bloomberg tickers, and descriptions. All data are daily (end of day). For motivation of asset prices and control variables and transformations of variables, see section 3 .

TABLE 10: List of variables

\begin{tabular}{|c|c|c|c|}
\hline Abbrev. & Bloomberg & Description & Unit \\
\hline \multicolumn{4}{|c|}{ Asset prices } \\
\hline SMI & SMI Index & Swiss market (equity) index & $\mathrm{pp}$ \\
\hline GB 10y & GSWISS10 Index & $\begin{array}{l}\text { Swiss government bond (yield), maturity 10y } \\
\text { (and similar for other maturities) }\end{array}$ & $\mathrm{bp}$ \\
\hline CP $7-10 y$ & ST171Y Index & SBI AAA 7-10 Y & $\mathrm{bp}$ \\
\hline Euro & EURCHF Curncy & Swiss Franc vs Euro exchange rate & $\mathrm{pp}$ \\
\hline USD & USDCHF Curncy & Swiss Franc vs US Dollar exchange rate & $\mathrm{pp}$ \\
\hline GBP & GBPCHF Curncy & Swiss Franc vs British Pound exchange rate & $\mathrm{pp}$ \\
\hline JPY & JPYCHF Curncy & Swiss Franc vs Japanese Yen exchange rate & $\mathrm{pp}$ \\
\hline \multicolumn{4}{|c|}{ Surprise (long-term bond futures) } \\
\hline Fut-US & TY1 Comdty & US Treasury futures & sd \\
\hline Fut-EU & RX1 Comdty & Euro - Bund futures & sd \\
\hline Fut-UK & G 1 Comdty & UK Gilts futures & sd \\
\hline Fut-JP & N 1 Comdty & Japanese gov. bond futures & sd \\
\hline \multicolumn{4}{|c|}{ Control variables } \\
\hline VIX & VIX Index & CBOE SPX volatility index & $\mathrm{pp}$ \\
\hline MOVE & MOVE Index & Merrill Option Volatility Estimate Index & $\mathrm{pp}$ \\
\hline
\end{tabular}

The maturities for government bonds include 10, 9, 7, 5, 4, 3, and 2 years (in sufficient data are available for other maturities).

We compute one-day changes as (i) differences in basis points for bond yields $\left(\left(x_{t}-x_{t-1}\right) \times 100\right)$, and (ii) changes in percentage points, for equities and exchange rates $\left(\left(x_{t}-x_{t-1}\right) / x_{t-1} \times 100\right)$, and compute two-day changes accordingly. 


\section{B Events}

TABle 11: Description of Fed and ECB UMP programmes

\begin{tabular}{|c|c|c|c|}
\hline Start & End & Programme & Description \\
\hline \multicolumn{4}{|c|}{ Federal Reserve Board } \\
\hline 25.11.2008 & 31.03 .2010 & $\begin{array}{l}\text { Large-scale asset purchases (LSAP } \\
\text { 1) }\end{array}$ & $\begin{array}{l}\text { Purchases of MBS, agency-related } \\
\text { securities and longer-term Treasury } \\
\text { securities up to a total of } \$ 1.75 \text { trillion }\end{array}$ \\
\hline 10.08.2010 & 30.06 .2011 & $\begin{array}{l}\text { Large-scale asset purchases (LSAP } \\
2 \text { ) }\end{array}$ & $\begin{array}{l}\text { Additional purchases of longer-term } \\
\text { Treasury securities of } \$ 600 \text { billion and } \\
\text { reinvestment of principal repayments of } \\
\text { LSAP1 purchases into longer-term } \\
\text { Treasury securities }\end{array}$ \\
\hline 09.08 .2011 & 31.12 .2012 & $\begin{array}{l}\text { Maturity extension programme } \\
\text { (MEP, Operation Twist) and } \\
\text { calendar-based Forward Guidance } \\
(\mathrm{FG})\end{array}$ & $\begin{array}{l}\text { Extension of the average maturity of } \\
\text { FOMC holdings of securities and } \\
\text { calendar-based forward guidance on } \\
\text { policy rate path }\end{array}$ \\
\hline 13.09.2012 & 17.12 .2013 & $\begin{array}{l}\text { Large-scale asset purchases (LSAP } \\
\text { 3) and threshold-based FG }\end{array}$ & $\begin{array}{l}\text { Open-ended purchases of agency } \\
\text { mortgage-backed securities and } \\
\text { longer-term Treasury securities at a pace } \\
\text { of } \$ 40 \text { billion and } \$ 45 \text { billion, } \\
\text { respectively, and threshold-based forward } \\
\text { guidance on policy rate path }\end{array}$ \\
\hline 18.12.2013 & 31.10 .2014 & Tapering and threshold-based FG & $\begin{array}{l}\text { Step-wise phasing-out of asset purchases } \\
\text { (reduction of purchases by } \$ 10 \text { bn per } \\
\text { month) }\end{array}$ \\
\hline \multicolumn{4}{|c|}{ European Central Bank } \\
\hline 27.03 .2008 & 01.04 .2010 & Extension of liquidity provision & $\begin{array}{l}\text { Allocation of liquidity through fixed-rate, } \\
\text { full-allotment tender and broadening of } \\
\text { eligible collateral basket }\end{array}$ \\
\hline 07.05 .2009 & 30.06 .2010 & $\begin{array}{l}\text { Covered bond purchase programme } \\
\text { (CBPP 1) }\end{array}$ & $\begin{array}{l}\text { Purchases of EUR } 60 \text { billion of covered } \\
\text { bonds }\end{array}$ \\
\hline 10.05.2010 & 06.09 .2012 & $\begin{array}{l}\text { Securities market programme } \\
\text { (SMP) }\end{array}$ & $\begin{array}{l}\text { Sterilized purchases of sovereign debt } \\
\text { securities }\end{array}$ \\
\hline 10.05.2010 & running & Extension of liquidity provision & $\begin{array}{l}\text { Re-establishment of liquidity allocation } \\
\text { through fixed-rate, full-allotment tender }\end{array}$ \\
\hline 04.08 .2011 & 01.03 .2012 & Extension of liquidity provision & $\begin{array}{l}\text { Extension of maturity of liquidity } \\
\text { provision operations }(6 \mathrm{~m}, 1 \mathrm{y} \text { and } 3 \mathrm{y})\end{array}$ \\
\hline 06.10.2011 & 31.10 .2012 & $\begin{array}{l}\text { Covered bond purchase programme } \\
\text { (CBPP 2) }\end{array}$ & $\begin{array}{l}\text { Additional purchases of EUR } 40 \text { billion } \\
\text { of covered bonds }\end{array}$ \\
\hline 06.09.2012 & running & $\begin{array}{l}\text { Outright monetary transactions } \\
\text { (OMT) }\end{array}$ & $\begin{array}{l}\text { Unlimited purchases of sovereign debt } \\
\text { securities }\end{array}$ \\
\hline 05.06 .2014 & running & "Draghi Swarm" & $\begin{array}{l}\text { Package of expansionary measures, } \\
\text { including } 4 y \text { liquidity operation and } \\
\text { preparation for the purchase of } \\
\text { asset-backed securities (ABSPP) and } \\
\text { other covered bonds (CBPP3) }\end{array}$ \\
\hline 22.01 .2015 & running & $\begin{array}{l}\text { Public sector purchase programme } \\
\text { (PSPP) }\end{array}$ & $\begin{array}{l}\text { Purchases of public sector securities } \\
\text { amounting to a total of EUR } 60 \text { billion } \\
\text { per month, including ABSPP and } \\
\text { CBPP3 }\end{array}$ \\
\hline
\end{tabular}


TABLE 12: Description of BoE and BoJ UMP programmes

\begin{tabular}{|c|c|c|c|}
\hline Start & End & Programme & Description \\
\hline \multicolumn{4}{|c|}{ Bank of England } \\
\hline 19.01.2009 & 10.06.2011 & Asset purchase programme (QE1) & $\begin{array}{l}\text { Purchases of private sector assets and } \\
\text { public sector bonds of } 225 \text { billion }\end{array}$ \\
\hline 06.10 .2011 & 03.07.2013 & Asset purchase programme (QE2) & $\begin{array}{l}\text { Additional purchases of private sector } \\
\text { assets and public sector bonds of } 150 \\
\text { billion }\end{array}$ \\
\hline 13.07.2012 & running & Funding for lending (FLS) & $\begin{array}{l}\text { Scheme incentivizing bank lending to } \\
\text { households and businesses }\end{array}$ \\
\hline 04.07 .2013 & running & Forward Guidance & $\begin{array}{l}\text { Threshold-based forward guidance on the } \\
\text { policy rate path }\end{array}$ \\
\hline \multicolumn{4}{|c|}{ Bank of Japan } \\
\hline 02.12 .2008 & 31.03 .2010 & $\begin{array}{l}\text { Liquidity provision: Special fund } \\
\text { supplying operations (SFSO) }\end{array}$ & $\begin{array}{l}\text { Expansion of the range of corporate debt } \\
\text { as eligible collateral in liquidity } \\
\text { operations }\end{array}$ \\
\hline 19.12.2008 & 31.12 .2009 & Asset purchase programme & $\begin{array}{l}\text { Annual purchases of government bonds } \\
\text { and commercial papers/corporate bonds } \\
\text { of Y21.6 trillion and Y3 trillion, } \\
\text { respectively }\end{array}$ \\
\hline 01.04 .2010 & 29.10 .2012 & $\begin{array}{l}\text { Liquidity provision (FRO - } \\
\text { replacing SFSO) }\end{array}$ & $\begin{array}{l}\text { Fixed-rate allotment of liquidity in } 3 \mathrm{~m} \\
\text { and } 6 \mathrm{~m} \text { operations amounting to Y30 } \\
\text { trillion }\end{array}$ \\
\hline 05.10 .2010 & 03.04 .2013 & $\begin{array}{l}\text { Asset purchase programme } \\
\text { (Comprehensive monetary easing - } \\
\text { CME) }\end{array}$ & $\begin{array}{l}\text { Purchase of government securities, } \\
\text { commercial paper (CP), corporate bonds, } \\
\text { exchange-traded funds (ETFs), and } \\
\text { Japan real estate investment trusts } \\
\text { (J-REITs), up to a total amount of Y101 } \\
\text { trillion }\end{array}$ \\
\hline 21.05 .2011 & running & $\begin{array}{l}\text { Growth supporting funding facility } \\
\text { (GSFF) }\end{array}$ & $\begin{array}{l}\text { Scheme to support to fund-provisioning } \\
\text { by private financial institutions }\end{array}$ \\
\hline 30.10 .2012 & running & $\begin{array}{l}\text { Stimulating bank lending facility } \\
\text { (SBLF) }\end{array}$ & $\begin{array}{l}\text { A fund-providing scheme to stimulate } \\
\text { bank lending }\end{array}$ \\
\hline 04.04 .2013 & running & $\begin{array}{l}\text { Quantitative and qualitative } \\
\text { monetary easing (QQME) and } \\
\text { calendar-based FG }\end{array}$ & $\begin{array}{l}\text { Purchases of JGBs, ETFs and J-REITs } \\
\text { with the goal of increasing the monetary } \\
\text { base by approximately Y } 80 \text { trillion } \\
\text { annually and intending to meet the } 2 \\
\text { percent price stability target over } 2 \text { years }\end{array}$ \\
\hline
\end{tabular}




\section{Recent SNB Working Papers}

2016-9 Severin Bernhard and Till Ebner: Cross-border Spill over Effects of Unconventional Monetary Policieson Swiss Asset Prices

2016-8 Pinar Yeşin: Capital Flows and the Swiss Franc.

2016-7 Signe Krogstrup and Cédric Tille: On the roles of different foreign currencies in European bank lending.

2016-6 Pascal Towbin and Sebastian Weber: Price expectations and the US housing boom.

2016-5 Raphael A. Auer and Cédric Tille: The banking sector and the Swiss financial account during the financial and European debt crises.

2016-4 Christian Hepenstrick and Massimiliano Marcellino: Forecasting with Large Unbalanced Datasets: The Mixed-Frequency Three-Pass Regression Filter.

2016-3 Alain Galli: How reliable are cointegration-based estimates for wealth effects on consumption? Evidence from Switzerland.

2016-2 Pinar Yeşin: Exchange Rate Predictability and State-ofthe-Art Models.

2016-1 Sandra Hanslin and Rolf Scheufele: Foreign PMIs: A reliable indicator for exports?

2015-13 Thomas Nellen: Collateralised liquidity, two-part tariff and settlement coordination.

2015-12 Jacob Gyntelberg, Mico Loretan and Tientip Subhanij: Private information, capital flows, and exchange rates.
2015-11 Philip Sauré: Time-intensive R\&D and unbalanced trade.

2015-10 Nikola Mirkov and Andreas Steinhauer: Ben Bernanke vs. Janet Yellen: Exploring the (a)symmetry of individual and aggregate inflation expectations.

2015-9 Aleksander Berentsen, Sébastien Kraenzlin and Benjamin Müller: Exit Strategies and Trade Dynamics in Repo Markets.

2015-8 Thomas Nitschka: Is there a too-big-to-fail discount in excess returns on German banks' stocks?

2015-7 Alin Marius Andries, Andreas M. Fischer and Pinar Yeșin: The impact of international swap lines on stock returns of banks in emerging markets.

2015-6 Jens H.E. Christensen and Signe Krogstrup: Transmission of Quantitative Easing: The Role of Central Bank Reserves.

2015-5 Petra Gerlach-Kristen and Seán Lyons: Mortgage arrears in Europe: The impact of monetary and macroprudential policies.

2015-4 Reto Foellmi, Sandra Hanslin and Andreas Kohler: A dynamic North-South model of demand-induced product cycles.

2015-3 Katarina Juselius and Katrin Assenmacher: Real exchange rate persistence: The case of the Swiss franc-US dollar rate. 
